\title{
Dede Korkut Kitabını Anlamaya Katkılar
}

\author{
Dr. Gülşen Seyhan Alıșık*
}

Eski Türk-Oğuz destanlarının kalıntılarından doğmuş olması kuvvetle muhtemel olan Dede Korkut Hikâyeleri eski gelenek, görenek ve yaşam biçimini yansıtması yanında, Türkçenin aklın örgüsü ile bezenmiş inceliklerini de bu günlere kadar taşımıștır'. Günümüze ulaşan yazmalar 16. yy. sonlarından kalmış olsalar bile, içerisinde doğduğu, oluştuğu dönemin dil özelliklerini koruyabilirler. Bir eser yüzyıllar içerisinde coğrafya ve zamana bağlı değişikliklere uğrasa dahi onun ana dokusu büsbütün bozulmuş olamaz. ${ }^{2}$ Hele bu eser halk tarafindan benimsenmiş bir destan, hikâye ya da söylence ise, ana metinden bütünüyle uzaklaşma ya da bütünüyle başkalaşmadan söz edilemez. Dede Korkut Kitabı bu özellikleri ile Oğuz Kağan Destanı ve Köroğlu Destanı ile karşılaştırılabilir. ${ }^{3}$

\footnotetext{
- Marmara Üniversitesi Fen-Edebiyat Fakültesi Türk Dili ve Edebiyatı Bölümü Öğretim Elemanı. Yakın Doğu Üniversitesi Fen-Edebiyat Fakültesi, Uluslar Arası Dede Korkut Sempozyumu'nda sunulmuştur (Lefkoşa 17.11.1999)

' iNAN, Abdülkadir: "Türk Destanlarına Genel Bir Bakıș", TDAYB: Ankara 1.954. 189-207 s.

2 ÖZTELLİ, [Hüseyin] Cahit: "Dedem Korkut Üzerine Yeni Bazı Düșünce ve Görüșler", Tïrk Folklor Araștırmalarr. İstanbul 1969(Temmuz) XII, 240. sy. 5331-5336. s. ; BAYKARA Hüseyin: "Dede Korkut Kitabı Üzerine Notlar" , Türk Külttürẗ: Ankara 1973 (şubat) XI. yıl 124. sy. (31) 223- (37) 229. s.

3 SÜMER, Faruk: Oğuzlar (Türkmenler) Tarihleri- Boy TeşkilatıDestanlarr. İstanbul, 1992, 277.s. Türk Dünyası Araștırmaları Vakfı Yayını: 89 ; ESIN. Emcl: "Tonga-Alp-Er" , Fen-Edebiyat Fakültesi Araștırma Dergisi Ord. Prof. Dr: Ahmed Zeki Velidi Togan Özel Sayısı, Erzurum 1985, Sayı:13, Fasikül I, 137-177. s. Atatürk Üniversitesi Fen-Edebiyat Fakültesi Yayını ; ÇifTÇioĞLU, H[üseyin] Nihal: "Dede Korkut Kitabı Hakkında", Azcrbaycan Yurt Bilgisi: İstanbul 1932, Cilt 1, 60-61. s
} 
Büyük göçerevli boyların dilinde dolaşıp ancak 16. yüzyılda yazıya aktarılmış olan Dede Korkut Kitabı ezberlenme kolaylığı, etkileyicilik ve kalıcılık çerçevesinde Türk Destan geleneğine uygun olarak ikilemeler ve koșuklarla donatılmıștır. Dede Korkut Kitabı'nda Türk tarihinin değișik tabakalarının izlerinin bulunmasına koşut olarak dil tabakalanmasından da söz edilebilir. İçinde her göçerevli boyundan; yaratıldığı günden, yazıya geçirildiği güne değin olan her dönemden, bir iki motif yanında söz ya da söz birlikleri bulmak mümkündür. Bu durum, gerek tarih ve gerekse dil bakımından eserin açık ve saklı zorluklarla dolu olmasına yol açmıștır. Bunlara bir de elde bulunan iki yazmanın çekimleme yanlışları ile dolu olması; tam yazma olan Dresden yazmasınin harekesiz, Vatikan yazmasının harekeli olmakla beraber eksik bulunması eklenince Dede Korkut'un dilini anlamak da anlatmak da güçleşir ${ }^{4}$.

Bu güne değin Dede Korkut üzerine pek çok yayın yapılmış ve bunlar hikâyelerin değişik özellikleri üzerinde derinleşmeyi, onları anlamayı kolaylaştırmış̦tır. Bunların içinde ikisi çok ayrı yere sahiptir. Dede Korkut Hikâyeleri'ni bilimsel yayma hazırlayarak, bilinmezlikten kurtarıp bilinir duruma getiren Ergin $^{5}$ ve Gökyay ${ }^{6}$ yayınları bu konu üzerinde çalışacaklara daima 1 şı tutacak ve ögreticiliğini yitirmeyecektir.

${ }^{4}$ FLEISHER, H. O. : Catalogus Codicum Manuscriptorum Orientalum Bibliothecia Regiae Dresdensis: Dresden,1831, No. 86. Mai,A: Scriptorum Veterum Nova Collectio, vol. IV, Parte 2a: Catalogus codd. Bibliothecea Vatıcana Arabicorum Persicorum Türcicorum: Romae,1821

${ }^{5}$ ERGiN, Muharrem: Dede Korkut Kitabı I. Giriş- Metin - Faksimile : Ankara 1958, TTK Basımevi.XVII+251 s. + 159+97 tıpkıbasım, TDK Yayınlarından, Sayı 169; ERGIN, Muharrem: Dede Korkut Kitabı II. Indeks - Gramer : Ankara 1963, TTK Basımevi.XII+[3] +433 s. TDK Yayınlarından, Sayı 219; ERGiN, Muharrem: Dede Korkut Kitabı. Metin Sözlïk : Ankara 1964, Ankara Üniversitesi Basımevi. VII+217 s . Türk Kültürünü Araştırma Enstitüsü Seri;IV , Sayı 2; ERGiN, Muharrem: Dede Korkut Kitabı. Metin - Sözlük: İstanbul 1983, Emin Ofset. 181 s, Ebru Yayınları 8.

"GÖKYAY, Orhan Saik: Dedem Korkudun Kitabr: İstanbul 1973, Milli Eğitim Basımevi (III)+359+DCLXXI s. Başbakanlık Kültür Müsteșarlığı Kültür Yaymları. 
Bir yazmayı okuyup, değerlendirerek yayına hazırlamak işin güç ve yorucu tarafidır. Biz, burada Dede Korkut'u yeniden okurken metinde karşılaştığımız, bizce farklı değerlendirilen birkaç önerimizi aktaracağız.

1. ağayıl ağ ayıl / ḳara il ḳara ayıl :

Dede Korkut'ta anlam olarak oturmuş buna karşın yapı olarak kuşku uyandıran sözcüklerden birisi ağayıl' dır. Gerek Ergin, gerekse Gökyay sözcüğ̈̈ ağayıl olarak tesbit etmişlerdir. Ergin (C.II, 5. s.) "ağıl, koyun ağılı (koyun sürüsü?)" olarak anlamlandırırken, Gökyay (159. s.) ise daha temkinli davranarak "Kaynak gösterilemiyor. Acaba ağıl kelimesinin arapça çoğulu mu?" biçiminde kuşkusunu dile getiriyor. Tercümede (Gökyay, Tercüme 7. s.) ise dipnot olarak "Koyun yatağı; çalıdan ve sazlıktan çevrilip içinde davar yatırdıkları yer." açıklamasına yer vermiştir.

Bizce ağayıl ile birlikte değerlendirilebilecek diğer sözcük de her iki yayında da kara il olarak okunmuş olan sözcüktür. Ergin bu sözcüğe (Tercüme 166. s.) "kara el, kara elde" biçiminde anlam vermiștir. Gökyay ise metinde $(103 / 12,23$. s.) ḳara il, kara illü olarak tesbit etmiş, ancak sözlükte (302. s.) ve tercümede $(167,170$. s.) sözcüğü yilin "Bütün tırnaklı davarların emciği, ineklerin emciklerinin sallanan torbası, koyun memesi, memenin süt toplayan yeri, süt torbası, meme süngeri." olarak değerlendirmiştir. Bu ikicillik ağayıl sözcüğündeki kuşkunun ḳara il'de de geçerli olduğunu gösterir. Sonuç olarak bu sözcükler, doğrusu birleşik sözcükler, bizce her iki yayında da anlaşılmazlığını korumuştur.

Dede Korkut'ta bugüne kadar ağayıl olarak tesbit edilen sözcük 14 yerde geçmektedir. Sekiz yerde ağayılda ağça koyun (D. 103/3, $118 / 4,139 / 9,145 / 5,163 / 11-12,167 / 2,196 / 13)$, üç yerde ağayılda tümen koyun (D. 18/1, 32/5, 33/9), bir yerde ağayıluñ koçları (D. 262/7) ve ağayılum güdende (D. 269/2) olarak geçer.

Buna karşılık ağıl sözcüğü tek başına üç yerde geçer: ḳıyan Güçi, Demir Güçci bu iki ḳardaşı yanma aldı, ağıluñ ḳapusını berkittü (D.39/12). Ağça koyun gördüginde kuyruk çarpup kamçılayan. Arḳasını urup berk ağıluñ ardın söken (D. 46/1,2). Delü Karçanı yalınçaḳ eyledi ağıla ḳoydı. Püreler Delü Karçara üşdiler (D. 88/3). 
Dede Korkut'ta koyunlar için kullanılan sıfatlar şunlardır; kara koyun, ağ koyun "ak koyun", ağça koyun "ağca koyun”, tümen koyun "tïylü koyun"” ve ağça yünlü tümen koyun "ağca yünlü tüylü koyun". Demek ki Dede Korkut coğrafyasında hem ağ "ak" hem de kara koyun mevcuttur. Destan örgüsünde renklerin ne denli önemli olduğunu ve bu renklerin Türk mitolojisindeki, kültüründeki yerini ayrıca anlatmaya gerek yoktur, ilgili yayınlarda bu konu geniş olarak incelenmiștir ${ }^{9}$.

Dede Korkut'un dil örgüsü içinde her tür ikileme destanî anlatımın bel kemiğini oluşturur. Böyle değerlendirildiğinde ak ve kara koyunun yahnisini (D. 10/6-7) dahi ayıran bir metinde, ak koyun ve kara koyunun ağıllarının da ayrı adlandırılmış olması düşünülebilir. Çünkü Türkçe ayrıntılı anlatımın seçkin örnekleriyle bezeli bir dildir. Metnimizde 3 yerde ağ koyun, 14 yerde ağça koyun geçmektedir, ağayıl ise; ağayılda ağça ḳoyun (D. 103/3, 104/1, $118 / 4,139 / 9,145 / 5,163 / 11-12,167 / 2,196 / 13)$, ağayılda ya da ağayıldan tümen koyun (D. 18/1, 32/5, 33/9), ağayıluñ ḳoçu (D. 262/7) ve ağayıl güdende (D. 269/3) biçimlerinde geçer. Sonuç olarak ağayıl metinde kara koyun için kullanılmamıștır denebilir.

\footnotetext{
"Mctinde tüy "tïy" (D.56/11-12) iki yerde geçmektedir. Tümen buradaki kullanımı itibarıyla ağ, kara, ağca gibi koyunun niceliğini değil, niteliğini belirten bir sıfat olarak da düşünülebilir. Böyle değerlendirildiğinde tïy+men>tümen "tüylü", tümen koyun "tüylü koyun" olarak anlamlandırılabilir.

* SÜMER, Faruk: "Dede Korkut Destanlarında Bazı Hayvanlara Dair" , I.Uluslararsı Türk Folklor Kongresi Bildirileri: Ankara 1976, 322. s." Destanlarda koyun ağça kelimesi ile vasıflandırılmaktadır. XIX. asra ait seyahatnâmelerde eski Oğuz bozkırlarında yaşayan kazaklar ile Hazar ötèı Türkmenlerinin koyunlarımın umumiyetle ak renkli oldukları belirtilir. Türkiye'de Orta Anadolı'daki koyunlar da umumiyetle ak renklidir. Buna karșılık Doğu Anadolu koyunlarmın kara renkte oldukları görülür."

" KARABAS, Scyfi: Dede Korkut ta Renk/cr: İstanbul 1996.
} 
Dede Korkut'ta iki yerde ḳara ayıl şöyle geçer: ḳara ayılum koyununı yüklü kodum koc mıdur, koyun-mıdur ant bilsem (D.211/9). Kara ayılda koyunumu (V.91/7-8). Kara ayıllu koyununı yüklü ḳodun, ḳoç oldı ( D.212/1 ). Kara ayılda ḳoyunuñ yüklü ḳoduñ (V.91/7).

$\mathrm{Bu}$ verilerden hareketle bu güne kadar ḳara il (D. 211/9, 212/1) olarak tespit edilmiş sözcüğün ḳara ayıl "kara sürü, kara koyun sürüsü"; ağayıl'ın ise ağ ayıl "ak sürü, ak koyun sürüsü, ak koyun ağılı" olarak değerlendirilebileceği kanısına varıyoruz.

A ̆ğl sözcüğü Eski Türkçe döneminden beri var olagelen, gerek tarihî gerekse yaşayan Türk lehçelerinde değişik biçim ve anlamlarıyla karşımıza çıkan bir sözcüktür ${ }^{10}$. Bunun da ötesinde bütün Altay dillerinde görülen bu sözcüğün bu dillerin ortak kaynaklarından geldiği de söylenebilir.

Eski Anadolu Türkçesi döneminde ağıl sözcüğünün /g/ sesi ile tesbit edilmiş olması ayıl biçiminin kabulünü güçleştirmektedir.

A ̆̆gl sözcüğü ayil biçimiyle Türk lehçelerinden Kırgızcada ve Altay dillerinden Moğolcada karşımıza çıkmaktadır. ${ }^{11}$ Doerfer Türkçe ağıl'ın Moğolca ayil'den daha eski olduğunu belirterek bu zincirin Tü.> Mog. biçiminde olması gerektiğini savunmuştur. Clauson, ise ayıl biçiminin, Kuzey-Doğu ve Kuzey-Orta dillerindeki biçimin, Moğolcadan geri ödünçleme olduğunu yazar ${ }^{12}$. Bu bilgilerin ıșı̆̆̆ altinda:

${ }^{10}$ INAN, Abdülkadir:Türk Etnolojisini Illgilendiren Birkaç Terim-Kelime Üzerine", TDA YB 1956, Ankara 1956, 179-195. s.

" SEVORTYAN, E. V: Etimologiçeskij Slovar Tjurskix Yazıkov (Obş̧̧etjurkskie i Meçtjurskie Osnovı na Bukvı) Moskova 1974, 768 s (s. 83-85); RASANEN, Martti: Versuch Eines Etymologischen Wörterbuchs der Türksprachern: Helsinki 1969533 s. (s. 8); DOERFER, Gerhard: Türkische und Mongolische Elemente im Neupersichen: C.I. Wiesbaden 1963,557 s. $(83-84)$

${ }^{12}$ CLAUSON, Sir Gerard: An Etymological Dictionary of Pre-Thirteenth Century Türkish: Oxford 1972, 83b. s. 
1. Dede Korkut'ta karşılaştı̆ı̆ımız ayil biçimi tıpkı ulus örneğinde olduğu gibi bir geri ödünçleme (reborrowing) olabilir.

2. Ağıl sözcüğündeki /g/ sesinin çok erken olmakla beraber batı sahasında $\mathrm{g}>\mathrm{y}$ değişimine uğradığı, özellikle de ağ ağıl biçiminde tekrardan kaçınılarak yumuşama sonucu ayıl'a dönüşmüş olabileceği düşünülebilir' ${ }^{13}$. Ancak bu ses olayını kabul etmek ḳara ayıl biçimini açıklamamızı güçleștirir.

3. Altay dillerinde de karşımıza değişik ses biçimleriyle çıkan bu sözcük Dede Korkut'un destan anlatısı içinde eskicil biçimini korumuş olabilir. Günümüz Türk lehçelerindeki /y/li biçimler de göz önününe alınırsa bu açıklamanın daha geçerli olacağını sanıyoruz ${ }^{14}$.

2. ala: Farklı köklerden olup, zamanla dilin ses yapısı içerisinde sesteş duruma gelen sözcükler vardır. Dede Korkut Kitabı'nda da bunun örneklerini görmek mümkündür. Metinde geçen ala sözcüğü bunlardan biridir. Bu sözü çözmekte hikâyelerde doyumsuz zenginlikte işlenmiş olan ikilemeler yönlendirici oldu. Sözlük bölümünde ala maddesine karşıllı olarak: Ergin (C.II, 11 s.), "ela, ala, karışık renk, alaca", Gökyay (161b. s.) ise "alaca, karışık renkli, benekli, rengarenk, yarı kırmızı, çizgili”" anlamlarını vermiştir. Ala sözcüğünün metindeki anlamlanı aşağıdaki biçimlerde tespit edilmeğe çalışıldd ${ }^{15}$ :

\footnotetext{
${ }^{13}$ Metinde $\mathrm{g}>\check{\mathrm{g}}>\mathrm{y}$ değişikliğine rastlanmıyor. Ancak Ergin bir yerde $\mathrm{k}>\mathrm{y}$ değișikliği tesbit etmiştir. Bu konudaki açıklama şöyledir: " Bu değişiklik her halde doğrudan doğruya değil, çekimde sedalılaşan ve yumuşayan k'nın aldığı ğ (y) şeklinde ortaya çıkmıștır. Dede Korkut'ta tabiî bu değişikliğin olmaması lâzımdır. Eserde gördüğümüze göre göye (D. 68/8) şeklinde sert konsonantların sedalılașması bahsinde de gördüğümüz gibi, bir yanlışlık olmalıdır. Bu şekil de çok yeni bir istinsah alâmeti gibi görünüyor." (II.c. 422-423. s.)

14 YUDAHIN, K. K (Türkçeye Çeviren TAYMAS, Abdullah): Kırgız Sözlüğ̈̈ï, Atatürk Kültür Dil ve Tarih Yüksek Kurumu Türk Dil Kurumu Yayınları: . 93, Ankara 1988, C.1, s.66a

${ }^{\text {is }}$ Dede Korkut'ta aynı imla ile yazılmış bu farklı sözcüklerin Azerbaycan Türkçesinde yazımları da ayrıdır ; Azerbaycan Dilinin Izahlı Lüğeti, 1. Cild
} 
ala < Ar. a"lā "çok güzel, pek güzel, iyi” :

Bazirgânlar dahı gice gündüz yola girdüler, İstanbul'a geldüler, dan dansulu ala yahıssı armağanlar aldılar(D. 69/12).

Yukarıdaki örnekte geçen ve yazmada ele biçiminde yazılmış olan ala her iki yayında da yanlış anlaşılmıştır. Bu Ar. a'lā'nın ses olarak Türkçeleşmiş biçiminden başka bir şey değildir. Yukarıdaki cümlede, bizzat metinde eș anlamlısıyla birlikte, 'güzel, çok güzel' anlamında eş anlamlı ikileme olarak yer alımıştır. Türkçede kullanılan eș anlamlı ögelerden biri genellikle dilin öz malı diğeri de alıntı öge olmaktadır, ala yahşı̧ı da Türkçe+alıntı öge kuralını bozmamıştır ${ }^{16}$. Bir sonraki yaprakta, Caya baksa çalımlu çal-ḳara ḳuş erdemlü, bir gözel yahşı yigit oldı (D. 70/4-5) cümlesinde her iki ögesi Türkçe olan ala yahşsı ile, anlamca eş bir ikileme ile karşılaşıyoruz. Bugün Azerbaycan Türkçesinde bu ikileme çoh yahşı ya da yaman yahşı biçiminde kullanılır.

A-G: Bakı 1966, Azerbaycan Elmler Akademiyası Neşriyatı, 82-83 s. "ala (1) sifet Garışıg renkli tükünün bir hissesi ağ o biri bașga renkde olan. ala at, ala inek. (2) Tahıl zemisi veya şum suvarıldığında su basmayıb guru galan yer.(3) Ganın pozulması neticesinde deride emele gelen ă̆ leke ( deri hesteliyi). (3) Yabanı bitki (4) sifet ve zerf Bir sıra mürekkeb sözlerin evvelinde sözün ifade etdiyi şeyde alalıg rengarenklik, ala-bulanıg, ağ renk ile garıșıglıg, yahud yarımçılıg, geyri müeyyenlik, dağınılıg ve s. kimi hasseler olduğunu bildirir." ; Azerbaycan Dilinin İzahlı Lüğeti 2. Cild D-J : Bakı 1980, Elm Neşriyatı, 258. s. "'la sifet (er.) En yüksek, en yahșı, en gözel. G. Zakir Leylinin bir letafeti yohdur:/ Ondan e'la gözel çohdur:

is ÇAĞATAY, Saadet: "Uygurcada Hendiadyoinler", DTCF Yıllık Calıșmaları Dergisi I, Türk Dili ve Edebiyatı Araştırmaları, Ankara 19401941, 41-42. s. ; CEFEROV, S.: Müasir Azerbaycan Dili (Leksika): Bakı1970, Maarif Neşriyatı, 29-37. s. ; TUNA, Osman Nedim: "Türkçenin Sayıca Es Heceli Ikilemelerinde Sıralama Kuralları ve Tabii Bir Ünsüz Dizisi", TDAYB 1982-1983:Ankara 1986, 213. s. Atatürk Kültür Dil ve Tarih Yüksek Kurumu Türk Dil Kurumu Yayınları: 527. 
"pek, daha, çok, en" anlamlarında pekiştirme ve kuvvetlendirme görevinde kullanıldığ yerler ${ }^{17}$ :

Așağıdaki örneklerde bu sözcük hem güzel hem de kuvvetlendirme, pekiştirme "pek, daha, çok, en" anlamlarıyla karşılanabilir:

Saya varsam dïkense olmaz, ḳalın oġuz bigleri bindi, Ala Taǵa ala leşker ava çıḳdı (D. 37/13). Boz ayġırın çekdürdi Beyrek bindi. Ala Taǵa ala leşker ava çıkdı(D. 76/2). Bu örneklerde yahş̧, iyi yanında çok, pek çok anlamlanı da mevcuttur.

Big yigidüm, kalabalık yaǵı gelse kayıtmaz idün̆, butuna ala ob tohynsa iñlemez idüin (D. 242/10). Bu örnekte de ala oh, yine ala oh'un sıfatı olarak pekiştirme görevinde "kuvvetli, keskin ok" olarak anlaşılabilir. Ala evren süvri cida (D. 129/5, 132/10), ala ḳalkan (D. 133/1), ala ḳollu sapan (D. 39/13). Yukarıdaki üç örnek de bu öbek içinde değerlendirilebilir.

Gökyay ala evren (s. CCCLXII) ve ala kollu (s. CCCLXIV) ile ilgili açıklamasında her ikisini de renkle ilgilendirmiştir: "Ala kollu diye nitelemesinden sapanın kollarının türlü renklerde iplerden veya sırımlardan yapıldığı anlaşıldığı gibi ayasının da ağırlığa dayanabilmesi için sağlam ve kuvvetli derilerden yapıldığı da görülür." "Ala evren benzetmesi, cıdanın renginin bir yılan gibi menevişli olduğunu anlatmaktadır."

"kırmızı, kızıl" anlamlarında kullanıldığı yerler:

kızıl ala gönder (D. 35/7, 60/3, 63/9-10, 66/5, 150/5, 202/10), kıııl ala gerdek (D.189/11-12), yañal ala iv (D. 7/2), ala iv (D. 7/1)

ala çadır(D. 14/4)

ala bargāh (D.271/2, 294/6)

${ }^{17}$ Azerbaycan Dilinin Izahlı Lüğcti 2. Cild D-J : Bakı 1980, Elm Neșriyatı, 258. s. "éla sifet (er.) En yüksek, en yahşı, en gözel. G. Zakir Leylinin bir letafeti yohdur:/Ondan éla gözcl çohdur. 
ala sayvan ( D.10/2,67/1, 71/2, 73/1, 122/11, 202/1, 235/6)

ala yorgan (D.198/4)

yañal ala iv'deki yañal biçimi tıpkı ḳııl ala gerdek'teki ḳızıl ala gibi bir eş ya da yakın anlamlı ikileme olmalıdır.

Ala ḳan, alaḳan alaġan "alıcı, yırtıcı"

ḳuşuñ ala ḳanını, ḳumaşıñ arusını, ḳızuñ gökçegini (D. 121/3, 212/8). Gerek Ergin gerekse Gökyay yayınlarında ala ḳan olarak yazılmış ve "renkli kan, kırmızı kan" gibi anlaşılmıștır. Oysa bu cümlede kuş, kumaş ve kız'ın en dikkat çekici özellikleri vurgulanmış olmalıdır. Bu yazıma ilk kez İlhan Başgöz dikkat çekmiş ve ḳuşun alaḳanın olarak okumuştur ${ }^{18}$. Buradaki alaḳan (< alaḳan) al- fiili kökünden "bir işi sürekli yapan, alışkanlık haline getiren" anlamındaki /-AgAn+/ ile türetilmiş "alıcı, yırtıcı" anlamında bir türev olabilir'. Alaḳan anlam ve yapıca eş olan çalağan "Uzun ganadları ve eyri dimdiyi olan iri, yırtıcı ḳuş." ile karşılaştırılabilir ${ }^{20}$. Bu sözcük yazmadaki biçime bağlı kalarak alakan okunup, "yırtıcı, alıcı" anlamı ile karșılanabilir. Buradaki problem ekin Eski Anadolu Türkçesinde /-agan+, -egen+/ biçiminde bulunmasıdır. / $/$ / $l_{1}$ biçim bir yazım yanlışı olarak düşünülebilir.

alaḳan "alıcı, yırtıcı" yeni bir okuma önerisi olarak değerlendirilebilir. $\mathrm{Bu}$ durumda cümle şöyle düzeltilmeli ve anlaşılmalıdır: ḳuşun ala ḳanını, ḳumaşın arusını, ḳızuñ gökçegini ...“ Kuşun alıcısını, kumaşın safını, kızın güzelini.”.

I* BAŞGÖZ, Illhan:"Dede Korkut Üzerine Notlar", Folklor ve Etmografya Araşstırmaları, Ankara 1985, s. 74

I" Bu ek/-AgAn+/ Dede Korkut Kitabı'nda iki yerde tebit edilmiștir: depegen (D.265/8) ve süsegen (D.265/9) . Ergin, Cll, 442.s "-agan, egen eki depegen $265 / 8$ ve süsegen 265/9 sözcüklerinde vardır. Ortadaki konsonantı yumuşamamıştır, Eski Anadolu Türkçesindeki şcklini muhafaza etmektedir." ${ }^{20}$ Azerbaycan Dilinin Izahlı Lüğeti 4. Cild S-S : Bakü 1987, Elm Neşriyatı, 412b. s. 
Ala ḳalı döşe- "kırmızı halı döşemek"

Toksan yirde ala ḳalı ipek döşemişidi (D. 36/4). Aḳ çadır dikdiler, ala ḳalı döşediler (D. 178/7). Ala ḳalı döşediler oturdı(D.179/2). Metinde üç yerde geçen ala kalı dösse- "en güzel halıyı sermek, döşemek" , "kırmızı halı döşemek", ya da bugünkü "âlâyı vâlâ ile karşılamak" olarak anlaşılabilir. Buradaki vâlâ " ince dokunmuş bir cins ipek"tir ${ }^{21}$. Dede Korkut Kitabı'nda altı yerde de ipck halça döse-, ipek halça sal- değimleri kullanılmıștır: Biñ yirde ipek halıçası dösenmiş-idi (D. 10/3, 67/2). Babası sevindi çetir otağ ala sayvan diktirdi, ipek halıçalar saldı, kiçdi oturdı (D. 73/12). Biñ yirde ipek halıçası dössenmiş idi (D. 122/11, 202/2, 235/7). Ala ḳalı ipek döşe- ve ipek halça dösse- anlamca eș kullanımlar gibi görünmektedir.

Ala "clâ" ala göz "elâ göz, Türkiye Türkçesi sarıya çalan kahverengi göz; Azerbaycan Türkçesi iri açık mavi göz": ${ }^{22}$

ala göz ( D. 32/12, 33/11, 76/6, 126/9, 126/9, 131/7, 140/1$6,186 / 7,197 / 10,206 / 9,208 / 2,211 / 10,212 / 2,231 / 3,232 / 7,233 / 3$, $238 / 9,239 / 1,239 / 4,239 / 7,239 / 12,241 / 10,242 / 1,246 / 3,252 / 13$, $259 / 10,262 / 8,266 / 12,267 / 8,280 / 3,297 / 4)$.

ala kııyma görklü göz (D. 192/6) söz bölüğü; ala, klyma, görklü göz " elâ, çekik, güzel göz" ya da ala ḳıyma, görklü göz "pek çekik güzel göz" biçiminde düşünülebilir.

Ala " karışık renk, renkli, alacalı bulacalı ":

ala başlu at (D. 41/1)

ala geyik (D. 2003)

${ }^{21}$ STEINGASS, F.: A Comprehensiv Persian-English Dictionary: London 1892, 1453a. s. ; REDHOUSE, Sir James W.: A Türkish and English Lexicon/Kitâb-ı Me'ânî-i Lehçe: Constantinople1890, 2124b. s

${ }^{22}$ Azerbaycan Dilinin Izahlı Lüğeti 1. Cild A-G: Bakı 1966, Elm Neșriyatı, 84a. s. alagöz(lü), sif[et]. İri acag mavi gözlü. Alagöz oğlan, alagöz gız.Kirpiginiñ esiriyem șol alagözlü fitneniñ.Nesîmî. 
ala ḳaz (D. 187/8)

ala köpek (D.184/5)

ala ördek (D. 280/13)

ala yılan (D.168/1, 175/11, 176/8)

ala $\tan$

Ala tañ ile yirün̆den țurı geldün̆. Oğulı țtdurduñ-mı (D. 194/9) Ergin ve Gökyay neşirlerinde ala țan biçimi birlikte değerlendirilmemiş, ala ve tan maddelerinde müstakil olarak değerlendirilmiştir. Burada ala tañ birlikte alınarak 'alaca, tan yerinin yeni yeni ağarmağa başladığı zaman, alaca karanlık” anlamıyla sözlüğe alınmalıdır. Azerbaycan Türkçesindeki ala-ġaranlıg ve alatoranlıg “ 1. Bir az ġaranlı̀g, yarı ışı่̀, yarı garanlı̀g. 2. Seher çağı, sübh gün çıhmaġ üzre olanda, dan yéri sökülen vaht." kullanımları ala țan biçimini destekler. ${ }^{23}$

ala tağ (D. 19/7, 20/6, 25/1, 37/13, 76/2, 181/7, 186/8, 200/3, 241/9, 244/12, 245/8, 257/9, 267/4, 293/11, 298/4) metinde kara tağ da olduğuna göre bu adlandırmada karşıt anlamlılıktan söz edilebilir mi?

ala yatan ḳara tağ (D. 206/12) biçimini de anlamak kolay değil, acaba ele yatan kara tağ (öylece yatan Kara Dağ) olarak anlaşılabilir mi? Ergin ala "alaca" (Ergin Tercüme 162. s.), Gökyay(100/19) ise Vatikan nüshasındaki ileri "ileride" (Gökyay Tercüme 163. s.) anlamların tercih etmişlerdir. Metinde o+ile birleşmesinden (monoftonglaşma) doğmuş olan öyle sözcüğü 16 yerde düz biçimiyle eyle, iki yerde de öyle (D. 78/9, 220/2) biçiminde geçer. Demek ki Dede Korkut Kitabı'nın yàzıldığı dönemde, daha sonra Azerbaycan Türkçesinde bütünüyle düzleşecek olan, öyle sözcüğü artık düzleşme sürecini tamamlamak üzeredir: o+ile $>$ öyle $>$ eyle $>$ éle. Bugün Azerbaycan Türkçesinde éle ve béle biçimleri sabitleşmiştir.

${ }^{23}$ Azerbaycan Dilinin İzahlı Lüğeti 1. Cild A-G: Bakı 1966, Elm Neșriyatı, 83b-84a, 85b-86a.s. 
Düz yazı ile ve halk için yazılmış eserler dil çalıșmalanı için çok daha elverişlidir. Çünkü bu eserlerde ağız farklılıklarını, ses değişmelerini, biçim genişlemelerini; yerine göre eskicil sözcükleri (alıntı sözcüklerden daha çok yerli sözcükler tercih edilir) bulmak mümkündür. Klâsik edebiyatın yaratıldığı klâsik yazı dili tutucudur ağız özelliklerini yansıtmaz. Bunlar göz önünde bulundurulunca Dede Korkut'ta yazıya geçirildiği dönemin ağız özelliklerinin bulunması olağan sayılamaz mı?

3. bebegüm (D.194/11):

Ergin bigüm, Gökyay bebegüm (93/28) biçiminde okumuştur. Gökyay'ın okuyuşu esas alınmalıdır.

Ala țañ ile yiründen țur geldüiñ,

Oğuls tutdurduñ mI...

Sen ge/ürsin bir bebegüm görinmez bağrım yanar.

Burada Kanturalı'nın anası gelini Selcen Hatun'dan oğlunu (bebeğini) soruşmakta, beğini değil.

4. gelin (D. 193/4):

Ergin gelen, Gökyay (93/5) gelin. Gökyay'ın okuyuşu doğrudur, gelen değil gelin olarak düzeltilmelidir. Kanturalı gözin açdı, k̦apaḳların ḳaldırdı. Gördi gelin at üzerinde geyinmiș sünüüsi clinde. Kanturah gözünü açtı, kapaklarını kaldırdı. Gördü ki gelin at üzerinde mızrağı elinde.

5. göz ḳaçuban (D. 175/13,176/10):

Ergin ve Gökyay $(85 / 13,31)$ göz ḳaḳuban okumuşlardır. Dresden'de kaçuban biçiminde yazılmıștır. Ergin kạk- "kakmak, vurmak, dikmek, başa kakınak, yüze vurmak" (C.II/161. s.) ; Gökyay ise CCXXIX. notta "Bu kelimenin söz dizisindeki karșılıkları 'Göz ḳaḳuban gönül alan anun görklüsï olur' cümlesinde tutmuyor. Bunu 'göz dikınck, gözünü dikip bakmak' gibi anlamak mümkündür sanırım.” diyerek 
kuşkusunu dile getirir ve sözlükte madde başı olarak alır, fakat anlam vermez. Tercümelerde ise Ergin ḳaḳmak, Gökyay ise göz dikmek ile karşılamışlardır ${ }^{24}$. Metin ḳaçu< $<\mathrm{ru}>$ ban biçiminde onarılabilir:

Göz ḳaçu<ru>ban köñ̈̈l alan anuñ görklüsi olur(D.175/13).

Göz ḳaçu<ru>ban köñül alan görklüsiniñ boynun öpem (D. $176 / 10)$.

Onun göz kaçırarak (seğirterek, süzerek) gönül alan güzeli olur.

Göz kaçırarak gönül alan güzelinin boynunu öpeyim.

kaç- Tarama Sözlüğ̈̈’nde 'kaçmak seğirtmek' anlamındadır. Gerek halk edebiyatında gerekse divan edebiyatında güzel ya da sevgili dik dik bakmaz, işveli bir göz süzüșle, göz göze gelmekten kaçınarak, gözünü kaçırarak, seğirterek bakar. Hâl böyle olunca Kanturalı'nın sevdiği sarı donlu Selcen Hatun'un da gözünü süzerek, kaçamak bakışlarla gönül alması gerek olur.

6. ḳabza (D.52/8, 119/2, 163/6):

Bu sözciik her iki yayında da 'bir bıçağın veya kılıcın tutulacak yeri' ck olarak Gökyay'da 'tutamak, sap, kulp; pençe, iktidar' anlamları ile karşslanmıștır. Üç yerde sözcük bu anlamlardan hị̧ biriyle karșılanamamaktadır: Dünlügi altun ban ivümün ḳabzası oḳul. Üç yerde geçen bu kalıp anlatım, evimin direği, dayanağı anlamında kullanılmıştır, kabzası değil. Bu sözcüğe bilinen anlaımı dışında Gökyay (230a. s.) "pençe, iktidar" anlaumını da eklemiştir. Bu iẹ̣ yerdeki kullanımı anlam olarak Ar. ḳabza ile karșılamak mümkün değildir. $\mathrm{Bu}$ anlam uyumsuzluğu sözcüğün Türkçe olabileceği kuşkusunu doğurmuştur.

${ }^{24}$ ERGIN. Muharrem: s.138 Göz kakarak gönül alan giizeliain boymun! öpeyim.” GÖKYAY, s.137 Göz dikip gönül alan guizclinm hoymm öpeyim. 
Derleme Sözlüğü'nde bu görüşü destekleyecek kapsa ve kapsak ad biçimi vardır "Çitten ya da aralıklı çakılan tahtalardan yapılmış bahçe kapısı "(Derleme Sözlüğü C.VIII 1635b, 2636a. s.). Azerbaycan Türkçesi ağızlarında ġapsağ "kapı" biçimi vardır: "ǵapsağ (Guba) çubugdan örülmüş (tohunmuş) gapı. Bağın ġapsağı açığdı. ${ }^{25}$. Türkmen Türkçesinde aynı sözcük gabsa "1. Kanat, penciräniñ gabsası pencerenin kanadı 2. Kapı” anlamlarında kullanılmaktadır ${ }^{26}$. Bu sözcük iki biçimde çözümlenebilir:1. Kabsa ad ve fiil kökü olarak yani ikili kök olarak değerlendirilebilir. 2 . Türkiye Türkçesi ve Azerbaycan Türkçesi ağızlarındaki biçimlerden hareketle Batı Türkçesinin genel temayülü olan son seste /-g/ düşmesi ile açıklanabilir: ḳabsa-g $>$ kabsa. Hem kapsa hem de ḳapsak/g̈apsağ biçimlerinin kullanılması ikinci açıklamanın doğruluğunu destekler. Yazmada iki yerde (D. 119/2, 163/6) kabżànın ضile yazılması bir yanlış yazım olmalıdır.

Bu veriler Dede Korkut Kitabı'ndaki ivümün ḳabzası yapısını evimin, çadırımın kapısı olarak değerendirmeğe olanak sağlar. Bu üç yerde ḳabza sözcüğünün anlamı kapı ile karşılanmalıdır.

\section{7. kör gözüm (D. 24/7)}

Ergin ve Gökyay (9/36) görür gözüm. yazmada kaf vav ve z açık olarak yazılmıștır. Burada /r/yerine /z/yi bir yazım yanlışı olarak kabul ederek metni Çıksun benim kör gözüm, a Dirse Han yaman segirür "A Dirse Han benim kör olası gözüm çıksın, kötü seğiriyor" biçiminde onarabiliriz. Bu durumda kör gözüm, kör olası göz ilencinden eksilti olarak düşünülebilir.

Dede Korkut Kitabı'nda köz ile ilgili bir deyim daha vardır: görür gözi görmez ol- (D. 157/6, 157/10). Bu deyime Çiftçi-Oğlu H. Nihâl dikkat çekmiş ve bu kullanımı Kül Tigin yazıtındaki paralel

\footnotetext{
${ }^{25}$ Azerbaycan Dilinin Dialaktoloji Lüğetr: Bakı 1964, 112. s.

26 TEKIN Talat, ÖLMEZ Mehmet, CEYLAN Emine, ÖLMEZ Zuhal, EKER Süer: Türkmence-Türkçe Sözlük, Simurg, Ankara 1995, 216a . s.
} 
biçimle karşılaştırmıştır ${ }^{27}$. İnim Kül Tigin kergek boldr. Özüm sakındım. Körür közüm körmez teg, bilir biligim bilmez teg boldı (Kül Tigin Kuzey cephesi 10. Satır) ${ }^{28}$. Dede Korkut Kitabı'nda : Delü Dumruluñ görür gözi görmez oldı, tutar elleri țutmaz oldı (D. 157/5-6). Menüm görür gözlerüm görmez oldr Țutar menüm ellerüm tutmaz old $ı$ (D. 157/10) . Her iki metin arasında yaklaşık sekiz yüzyıllık bir zaman farkı olmasına rağmen bu deyimde yapı, anlam ve kullanım bakımından tam bir örtüșme söz konusudur: Körür közüm körmez teg boldı / görür gözi görmez oldı.

Bu deyim Dede Korkut Kitabı'nda bir yerde de eksiltili biçimi ile kullanılmıştır. Zîrā ağlamaḳdan gözleri görmez olmış-idi (D. 119/12) . Görür gözleri görmez olmuş idi yerine görmez olmuş idi.

\section{8. kurt sinirli:}

Bu sözcük D. 22/12 ḳorḳut sinirli, V. 12/12'de ḳurt sinirli biçiminde yazılmıştır. Ergin D. nüshasını, Gökyay ise V. nüshasını metinde ve tercümede esas almıștır. Korḳut sinirli değil kurt sinirli okuyuşu tercih edilmelidir: Dirse han ḳurt sinirli ḳatı yayın eline aldı. Dirse Han kurt kirişli, katı yayını eline aldı. Gökyay (CCCLXI. s.) Radlof'tan şu bilgiyi aktarır: "Solkoy ve Teleütlerin yayları dört kat idi , bir kat boynuz, sonra bir kat ağaç, bunun üzerine sinirden bir kat daha ve son olarak da kayın ağacından bir kat daha vard.."

9. oturmaz (D. 29/11):

Ergin ve Gökyay (12/24) arturmaz. Dresden'de açık olarak arturmaz yazılmıştır; fakat bu yazım cümlenin anlaşılmasımı güçleştirmektedir. /r/ ve /vav/ın yazımdaki yakınlığı göz önüne alınarak arturmaz’ın bir yazım hatası olduğu düşünülebilir.

27 Çiftçi-Oğlu H. Nihâl [ATSIZ]: "Dède Korkut Kitabı Hakkında", Azerbaycan Yurt Bilgisi, Y1l 1, Sayı 2, İstanbul 1932, 61-62 s. ERGIN, Muharrem: Orhun Âbideleri, Milli Eğitim Basımevi, İstanbul 1970, s. 59

${ }^{28}$ ERGiN, Muharrem: Orhun Âbideleri, Milli Eğitim Basımevi, İstanbul 1970, s. E? 
Ol ḳırk nāmerdler bunı tuydılar, ne eyleyelüm diyü tanıștılar? Dirse Han eger oğlançuğın görür ise oturmaz bizi hep ḳırar didiler (D.29/10-12).

Dirse Han eğer sevgili oğlunun durumunu görür ise yerinde durmaz (oturmaz), hepimizi öldürür, dediler. Bu bağlamda Gökyay ve Ergin'in "geriye burakmak, sağ burakmak" biçimindeki anlamlandırmalarıyla karşılaştırılabilir.

10. sal- "sermek, döşemek"

Ergin sal- madde başında (C. II, 256. s.) "sermek" anlamını vermiş, Gökyay ise bu anlama değinmemiş̧ir. Metinde üç yerde ala kalı đöşe- (D. 36/4, 178/7, 179/2); beş yerde de ipek halçal halçası döse(D10/3, 67/2,122/11, 202/2, 235/7 ) ve bir yerde de ipek haliçalar sal-, Babası sevindi çetir otağ ala sayvan diktirdi, ipek halıçalar sald, kiçdi oturdı (D. 73/12) biçiminde ifade edilmiştir. Bu kullanımlar sal-ve döse'i cş anlamlı olarak değerlendirme imkânı vermektedir.

11. togayın (D. 49/3):

Ergin bu sözcüğü toġanın, Gökyay (22/22) ise doğanın biçiminde okumuş ve her iki yayında da "yeniden doğanını" biçiminde çevrilmiştir. Salur Kazan'ın Evinin yağmalandığı boyda Karaçuk Çoban, Salur Kazan'm düșmanları ile savaşır ve üç yerinden yaralanır, bu hâlde iken Salur Kazan'dan evini kurtarmak için izin ister:

Kafire men varaym,

Yeniden togàyın, öldüreyin.

Kafirin üzerine ben gideyim, yeniden cana geleyim (canlanayım), öldüreyim, biçiminde anlaşılmalıdır. Burada söz dizimi ve ses ıyımu da tog̉ayın biçimini düşündürmektedir.

12. tuğlat- (D. 138/10): Sözcük, Ergin ve Gökyay'da tıkatmak, kapattırmak anlamlarında doğru olarak tespit edilmiştir. 
Bu sözcüğün kökü DLT'teki 'herhangi bir nesnenin tıkacı, kapağı; su bendi, büvet, germeç' anlamındaki tug sözüdür ${ }^{29}$. Buradan tuğla- (tuğ+la-t-) 'suyun gediğini yarığını kapatmak' anlamını karş̣layan fiil türetilmiştir. Clauson'da bu söz tog̉la- biçiminde o ünlüsü ile yer alaktadır ${ }^{30}$.

13. yaralanup (D. 25/7) Ergin paralanıp, Gökyay(10/16) yaralanıp. Gökyay'ın okuyuşu doğrudur. Fakat Gökyay da bir üst satırdaki kāfine sözcüğünü eksik olarak kāfirlere okumuştur, her ikisi de düzeltilmelidir:

Azġun dinlü kāfire ben varayım,

yaralanup kazılık atımdan inmeyince...

14. yayḳandığında (D. 110/2): Ergin ve Gökyay'da bu söze "çalkalanmak, dalgalanmak, yıkanmak" gibi anlamlar verilmiş. Oysa yayḳanmak burada, "yayık yayılmak" anlamındadır. Tarama Sözlüğ̈̈'nde yay-maddesinde ilk anlam "yağını çıarmak için yoğurdu yayıkta çalkalamak" tır. Demek ki bu türemiş sözcük yay-1-k+ adından +a- ile fiil yapılmıș ve -n- dönüşlülük eki ile genişletilmiştir.

Yayḳanduğında yağ tökilen bol nimetlü. Bu cümle, "yayık yayıldığında, yayığından yağ dökülen ( taşan) bol nimetli” olarak anlașılmalıdır.

15. yiñil (D.178/5, 242/6, 303/4): Ergin ve Gökyay (86/25. s.) bigler biçiminde okumuşlardır. Yazmadan hareketle böyle okumak mümkün değildir. Onlarca diğerleri gibi bu da bir çekimleme yanlışı olarak düşünülebilir. ${ }^{31}$ D. 303/4'te /be/ / kef/ ve /lam/ ile diğerlerinde ise /ye/ / kef/ ve /lam/ ile yazılmıștır. Metne dayanarak bigil biñil yigil yiñil biçimlerinde okumak mümkündür. $\mathrm{Bu}$ sözcük geçtiği yerlerde yigit ile birlikte kullanılmış, başka bir değişle hiç yalnız

\footnotetext{
${ }^{20}$ DLT C.II, 344. s.

30 CLAUSON, 470a. s.

${ }^{31}$ TEKiN, Talat: "Dede Korkut Hikayelerinde Bazı düzeltmeler" , TDAYB 1982-1983:Ankara 1986, 142. s. Atatürk Kültür Dil ve Tarih Yüksek Kurumu Türk Dil Kurumu Yayınları: 527.
} 
kullanılmamıștır. $\mathrm{Bu}$ kullanım bize bu yapının da bir ikileme olabileceğini düşündürdü. Metinde üç yerde, bigler yerine yiñil okunmalı ve yigit yiñil "genç, delikanlı" anlamı ile karşılanmalıdır. Bu sözcük Semih Tezcan'ın tespitine göre Süheyl ü Nev-Bahār'da "gençler, delikanlılar" anlamında geçmektedir. ${ }^{32}$ Böylece, yiğit yiñil biçimi de Dede korkut'taki eş anlamlı ikilemelere eklenmelidir.

16. üz gözünde (D. 27/6): Dresden yazmasında açı olarak üz göz, Vatikan'da ise öz gevde (V. 65/6) biçiminde yazılmıştır.

Üz gözünde canuñ var-ise oğul ver ḩaber maña, ḳara başum kurbān olsun saña.

Oğul, yüzünde gözünde canlılık işareti var ise bana bildir, kara başım sana kurban olsun. Türkçede organ adlarıyla yapılan ikilemeler ve deyimler yaygındır (elden ayaktan düşmek, yüzüne gözüne bulaştırmak vb). Bu kullanım da yakın anlamlı bir ikileme olarak değerlendirilebilir. Söz konusu metin Dede Korkut da olunca ikilemeleri anlamadan metne hakim olmak çok güçtür.

17. yalçımasun (D. 19/3, 42/3, 70/11, 86/6, 90/2, 90/5, 90/6, 93/6): Dede Korkut Kitabı'nda yarımasun yalçımasun biçiminde geçen bir ilençtir. Ergin ve Gökyay yayınlarında ilenç olarak anlam verilmiş fakat kökenine değinilmemiş̦tir. Clauson, sözlüğünde bu fiilin yalçı- yanında Çağatayca yalçı-, Özbekçe yalçi-/yolçi-, Kıpçakça yolşi-, Kırgızca jalçı- biçimlerini de tespit etmiştir (EDPT922a) $^{33}$. Yarımasın yalçımasın ilenci Dede Korkut'ta sıkça gördüğümüz eş anlamlı ikilemeler içinde değerlenirilmelidir

${ }^{32}$ TEZCAN, Semih: "Süheyl ü Nev-Bahâr Üzerine Notlara Birkaç Ekleme" Türk Dilleri Araştırmalarr. Ankara 1995, C. 5, 242. s.

33 CLAUSON, Sir Gerard: An Etymological Dictionary of Pre-Thirteenth Century Türkishr: Oxford 1972, 922 a. s. ; yalçı:- not noted before the medieval period but see yalçıt-; survives, meaning 'to get what you want, or need'. 


\title{
İki Öncü Roman: Don Kişot Ve Araba Sevdası
}

\author{
Dr. Nihayet Arslan ${ }^{*}$ \\ "Çocuklar karıştırıyor, gençler \\ okuyor, yetişkinler anlıyor, yaşlılar yüceltiyor."
}

Don Quijote

İsmail Habip Sevük, Türk Teceddüd Edebiyatı Tarihi adlı kitabında, Recaîzade Mahmut Ekrem'in üç yönüyle edebiyat tarihimizde yaşayacağını söyler: "Biri, 'Yakacık'ta Mezarlık Âlemi' şairi olarak, diğeri Talim-i Edebiyat ve Takdir-i Elhân müellifi sıfatıyla, üçüncüsü de Araba Sevdası'nı yazdığı için."' Gerçekten de, Araba Sevdası, Türk romanının oluşum aşamasında en anlamlı roman olması yanında, Türk romanını, tarihî akıșı içinde anlamlandıran önemli bir belgedir.

İçinde doğdukları kültürlerin önemli kırılma noktalarında ortaya çıkan, dünya edebiyatının en büyük klâsiklerinden olan Don Kişot ile ilk modern Türk romanı Araba Sevdası arasında nasıl bir ilinti olabileceği sorusu bizi, her iki romanı yaratan tarihsel ve toplumsal koşullar üzerinde düşünmeye yöneltti.

Avrupa'nın büyük dönüşümünü gerçekleştirdiği, Rönesans'1 yaşadığı yıllarda, 1605 tarihinde adı yazarından daha çok ünlenecek olan Don Kişot doğar. Doğum yeri İspanya ise, 1492 'de Kristof Kolomb'u "Yeni Dünyalar"1 keşfe gönderen, 1520'de Aztek İmparatorluğunu, 1529 'da İnka'ların ülkesini fethederek "Yeni Dünya"dan gemilerle altın, gümüş ve kıymetli mücevheratın ve eşyanın taşındığı Avrupa'nın güçlü bir devletidir. Diğer yandan, Yeni Çağ'a giren, Rönesans'ını yapmış Avrupa, bilimsel devrimlerine (Descartes, Galileo, Kepler...) hazırlanmaktadır. Orta Çağ değerleri tarihe gömülmüş; aklına, kendi iradesine, kendi bilgisi ve kazancına güvenmek durumunda olan yeni bir insan doğmuștur. Bir zamanlar, "Senyör"ün ve "Kilise"nin egemenliğinde, kendi nefsi için değil de, onların belirlediği değerler için savaşan şövalyelerin çağı artık çok

\footnotetext{
AÜ Dil ve Tarih-Coğrafya Fakültesi Türk Dili ve Edebiyatı Bölümü Ögretim Elemanı.

1 İsmail Habip Sevük, Türk Teceddüd Tarihi, Matbaa-i Âmire, İstanbul 1340, s. 205.
} 
gerilerde kalmıştır. "Kilise" toplum üzerindeki nüfuzunu kaybetmeye başlamış, aristokrasi toplumdaki işlevini yitirmiştir. Bununla birlikte, bu dönemde, şövalye romanlarının matbaa baskıları hâlâ elden ele dolaşarak bir kısım insanları etkilemeye devam etmektedir. Bu romanların amansız bir okuyucusu olan Don Kişot ise, bu yeni dünyada geliri daralan, toplum içindeki yerini ve ișlevini kaybeden bir köy soylusudur (hidalgo) $)^{2}$. Yardıma muhtaçları, haksızlığa uğrayanları, zorda kalmış genç kızları koruyan, cesur ve yenilmez savaşçılar olan gezgin şövalyelerin hayat hikâyelerini, kapandığı evinde okuyarak günlerini geçirmektedir. Onların, uğrunda savaştıkları yüksek değerler, cesaret, adalet, fedakârlık ve sonsuz sadakat duyguları burjuvazinin yaygınlaştırdığı egoizm sonucunda tarihe karışmıştır. Don Kişot, sonunda, gerçekle romanlardaki dünyayı birbirine karıştırır ve aklı bulanır. Okuduğu şövalye romanlarındaki hayatı gerçekleștirmek için sonu gelmez serüvenlere atılır.

Maddîleșen, bundan böyle ortak bir inançta bulușmak yerine, her biri kendi kaderini yapmak zorunda kalan çağının insanları ve değerleriyle uyuşamayan Don Kişot, Modern Çağ'a geçişte yaşanan bunalımı yansıtır: Bu, inanç çağından akıl çağına geçișin, destan çağından felsefe çağına geçişin (birey) bunalımıdır. Cervantes, bütünlüğü iki ayrı zihniyet arasında parçalanan bu insandan, romansal büyük çatışmayı yaşayan kahramanı Don Kişot'u yaratır. Yazarın kahramanı ile arasına koyduğu ironik mesafe, onun kişiliğinin her yönünü gözler önüne sererek geçiş çağındaki insanın, dünü, bugünü ve geleceği kavraması için yoluna ışık tutar.

Kitabın Roza Hakmen tarafından yapılan İspanyolca aslından çevirisi Don Quijote 'ye yazdığı önsözde Jale Parla, Don Kişot'u ${ }^{3}$ şöyle tanımlar:

"Don Quijote toplumla ters düșen modern roman başkişisinin öncüsïdür. Cesareti, azmi, adalet ve eşitlik duygusu, katıksız sadakati, kimliğini kendi kendine belirleme kararı, опи bekleneceğ $i$

\footnotetext{
2'Ispanyol soylusu

${ }^{3} \mathrm{Bu}$ ismin İspanyolca aslına göre yazılıșı Don Quijote'tur. Ancak 1996 yılında yayımlanan Roza Hakmen'in aslından yaptığı ilk çeviriye kadar Fransızca çevirilerine bağlı olarak Türkçe'de Don Kişot olarak yerleşmiştir. Biz de bu yayğın kullanıma bağlı olarak Don Kişot demeyi tercih ettik.
} 
iizere destansı bir kahraman ya da efsanevî bir yiğit yapmaz. Tersine, sürekli yenilgiye uğrayan, dıșlanan, anlaşılmayan anlaşılırsa da alay edilen, kazandiğı zaferlerde bile ardında buruk ya da acı bir tat birakan, özetle, artlk toplumla bütünleșmesine olanak olmayan, yabancılaşmış bireydir o. $"{ }^{4}$

Kendi çağının tutunamayan insanı, burjuvazinin getirdiği yeni değerleri benimsemede zorlanan Don Kişot, şövalyelik çağına tutkusunu şöyle dile getirir:

“... ben sular tanrısı Neptün değilim; akıllı olmadığım hâlde kimsenin beni akıllı sanması için de uğraşmıyorum. Ben sadece dïnyaya gezgin şövalyelik tarikatinin sancaklarının dalgalandığı $o$ mutlu çağı canlandırmamakla düştüğü büyük hatayı anlatmak için uğraşıyorum. Fakat bizim yoz çağımız, gezgin şövalyelerin, krallıkların savunmasını, bakirelerin korunmasinı, öksüzlere, yetimlere yardımı, kibirlinin cezalandırılmasını ve alçakgönüllülerin mükâfatlandırılmasını üstlendiği, görev bildiği çağların sahip olduğu mutluluğu yaşamayı hak etmiyor. Şimdiki şövalyelerin çoğunu örme zırhlarının halkaları değil, giydikleri damasko, brokar ve diğer zengin kumaşlar okşuyor; kırlarda gökyüzünün bütün şiddetine maruz, tepeden tırnağa zırhl uyuyan şövalye yok..." (s. 459)

\footnotetext{
${ }^{4}$ Miguel de Cervantes Saavedra, La Mancha'll Yaratıcı Asilzade Don Quijote, Çev. Roza Hakmen, Yapı Kredi Yayınları, 3.b., İstanbul 1999, s. 26. (Alıntılar bu baskıdan yapılmıștır.)

Avrupa Edebiyatı ve Biz kitabında, Don Kişot'un dünya edebiyatındaki önemini belirten ve eserin değerini hakkını vererek anlatmaya çalışan İsmail Habip Sevük dışında, Jale Parla'ya kadar edebiyatımızda, Don Kişot hakkında özgün bir çalışma ne yazık ki yapılmamıștır. Ahmet Midhat Efendi, Don Kişot'un okuduğu romanların etkisinde kalarak olağanüstü olaylara ve büyülere inanmasından esinlenerek Çengi romanındaki Daniş Çelebi'yi yaratır. Bunun dışında, Don Kişot, en çoğu, yel değirmenlerini dev sanarak savaşan aptal kahraman olarak tanınır. Bu nedenle, böyle bir mecazî anlam kazanarak dilimize geçen "donkişotluk" Türkçe Sözlük'te "gereğ $i$ yokken kahramanlık göstermeye kalkışma durumu” olarak tanımlanmıștır. Oysa Fransa'daki ansiklopedi ve sözlüklerde bu pejoratif anlam yoktur. "donquichotisme"in, Don Kişot'un karakterini bütün olarak ifade eden olumlu bir anlamı vardır.
} 
Don Kişot'un peşinde koştuğu ideal değerler, aynı zamanda Hristiyanlığın yüce değerleridir. Sadık silâhtarı Sanço'ya şöyle seslenir:

"Yine de Hristiyan, Katolik ve gezgin şövalye olan bizler, yașadığımız fani hayatta kazanılan şöhretin gururuna kapılmayıp, göksel, tanrisal ebediyete sahip olan gelecek yüzylların șerefiyle ilgilenmeliyiz..[...] Devleri öldürerek gururu öldürmeliyiz; cömertlik ve yücegönüllülükle haseti; serinkanllllk ve ruh huzuruyla öfkeyi; az yiyip çok uyanık kalarak oburluk ve uykuyu; irademizi tâbi kıldığımız sevgiliye olan sadakatimizle, sefahat ve șehveti; dünyanin dört bir yanın dolașıp bizi hem Hristiyan hem iyi şövalye yapacak imkânlart arayarak tembelliği öldürmeliyiz."(s. 495)

Don Kişot bu değerleri tekrar canlandırmak için eyleme geçmiştir. Ne yazık ki, dünya eski dünya değildir. Devler, büyücüler, tüm olağanüstülükler gibi, onun inandığı değerler de olağanüstü bir dünyaya ait olarak kalmışlardır.

Milan Kundera, Don Kişot'un karşı karşıya kaldığı sorunsalı şöyle netleștirirken modern romanın doğuș koşullarını da vurgular:

"Tanrl evreni ve değerler düzenini yönettiği, iyiyi kötüiden aytrdiğl, her şeye bir anlam verdiği yeri yavaş yavaş terkederken Don Kişot evinden çıktı ve artık dünyayı tanıma gücünden yoksundu. Don Kişot yüce yargıcın yokluğunda, birdenbire korkunç bir karmaşıklığın içinde ortaya çıktı: tek tanrısal doğru, insanların paylaştığı yüzlerce görece doğruya ayrıșt. Böylece Modern Çă̆'la birlikte roman imgesi ve modeli de doğmuş oldu. ".

Kușkusuz, bir tek şövalyelik konusunda aklı başından giden, bunun dışında her konuda akıllıca, hatta bilgece fikir yürüten, kendisini Yeni Çağ'a hazırlayan tarihsel birikimi inkâr etmeyen, çağını kavrayabilecek derinlemesine okumaları olan Don Kişot'la Araba Sevdası 'nın kahramanı Bihruz Bey arasında derin bir uçurum vardır. Ortak yanları, yaşadıkları çağla olan uyumsuzluklarıdır. Don Kişot, geçiş çağının bunalımını ve onu yaşayanları temsil ettiği gibi, Bihruz Bey de Osmanlı batılılaşmasının bunalımlı toplumunu temsil

${ }^{5}$ Milan Kundera, Roman Sanatı, Çev.İsmail Yerguz, Afa Yayınları, İstanbul 1989, s. 14. 
eder. Ancak Don Kişot, bir dönüşümü gerçekten yaşayan bir toplumla ters düşerken, Bihruz Bey, yaşadığı topluma birdenbire dayatılan bir yaşama modeline uymak zorunda kalmanın şaşkınlığını yaşar.

Tanzimat'a kadar, Osmanlı'nın yüzyıllardır değișmeyen bir yönetim biçimi ve otarşik yapısı vardı. Bunun doğal sonucu olarak, sadece kendi içinde evrilmelerle kalan, özünde bir değişiklik göstermeyen bu toplumun her katmanı, içinde bulunduğu durumu kabullenmiş, iyi ve kötü yanlarıyla toplumun değerler bütünlüğünü benimsemiş, yapısında herhangi önemli bir çatlak olmaksızın varlığını sürdürmüștü. Ancak, ekonomik dengesini fetih ve genişlemelerle sağlayan Osmanlı, dış engellemeler ve tehditlerle karşılaştığında, iç bütünlük de bozulmaya başlamıştır. Bu noktada köklü değişim şart olur. Batı medeniyeti karşısında, büyük olduğu nisbette zayıf olduğunu anlaması Osmanlı'yı, yönetim mekanizmasını güçlendirecek çareler aramaya iter. $\mathrm{Bu}$ yol beraberinde, karșısındakinin gücünü kabul etmek, onun yolunu izlemek, dolayısıyla onu taklit etmek sonuçlarımı getirir. O zamana kadar hiç bir değişiklik göstermeden belirli bir çizgide yürüyen bu toplumun insanından, yeni bir insan yaratma çabasına girildiği bu dönemde, Bihruz gibilerin de içinde bulunduğu lokomotif toplum tabakası makas değiştirmiştir. Artık toplum eskisinden tamamen farklı yeni bir yola girecektir. Yönetim biçiminin gereği olarak merkeze bağlı büyük kitleler, ağır bir dişli gibi merkezin hareketine, çok ağır bir dönüşle uymak zorunda kalacaklardır. Araba Sevdası, işte bu emsalsiz kırılma noktasının romanıdır. Kahramanı da birdenbire ortaya çıkan, bu "nevzuhur" "yeni insan"ın, Tanzimat modelinin kendine özgü bir tipidir.

Artık kendi yöntemleri işlemez hâle gelen, kendi değerleriyle varlığını idame ettirmesine imkân kalmadığını gören toplum, bir sorunsal karşısındadır: Batılılaşma sorunsalı.

Birçok yazarı bu dönemde yazmaya iten bu sorunsaldır. Ekrem de bunlardan biridir. Ancak o, okuruna, yani topluma, bu konuda yol gösterici olmak, hedef göstermek, buyurmak için yazmaz. Bir sanatkâr olarak, araya girmez. Anlatıcısıyla, kahramanıyla okurunu başbaşa bırakır.

Ekrem, bu romanı yazdığı yıllara kadar Batı kültürünü özümsemeye çalışan bir edebiyat adamıdır. Bütün geçmişi, birikimi, tereddütleriyle kendisinin de içinde yaşadığı sürecin ve toplum tabakasının bir parçası olarak kahramanına bakar. Bihruz'un kendisi hayaller içinde yaşasa da, bir hayal ürünü değildir. Yaşayan bir kişi, 
toplumda yaşayan kişilerden biridir. Araba Sevdası'nı yerli ve özgün yapan onun bu özelliğidir. Bu yanıyla, Türk romanının modern romanla buluştuğı anı temsil eden, Türk batılılaşmasının, dolayısıyla Türk edebiyatında roman macerasının anlamını kavramada bize yol gösteren olarak Araba Sevdası roman tarihimizde en önemli köșe taşıdır.

Araba Sevdası'nda ilk bakışta göze çarpan özellik ve eleștirmenlerin en çok üzerinde durdukları husus, romanda Batı taklitçisi züppe tipinin işlenmiş olmasıdır. Ahmet Midhat Efendi'nin Felâtun Bey'inin bu alanda ilk örnek olduğunu ve Türk roman tarihi boyunca birçok yazar tarafından bu tipin ele alındığını Türk edebiyatı ile ilgilenen herkes bilir. Bu olgunun batılılaşma sorunsalına bağlı olduğu da bilinen bir gerçektir.

$\mathrm{Ne}$ var ki, yazarının kullandığı yeni teknikler Araba Sevdası'nı, bu tipin işlendiği diğer romanlardan belirgin bir şekilde ayırır. Yazarın, kahramanı karşısındaki tutumu da Bihruz Bey'i benzerlerinden farklı kılar. Araba Sevdası'nı, yazarın gençlik dönemini de içine alan yakın geçmiş üzerine bir değerlendirme olarak düşünmek mümkündür. Bu değerlendirmenin nesnel ve gerçekçi olması kadar, yazarın burada kahramanıyla arasına koyduğu ironik mesafe de çoğul okumalara olanak vererek romanın anlamını zenginleştirir ve böylece, Bihruz'un yalınkat kişiliği, çağının toplumunun kültürel trajedisiyle birleşerek derinleşir. Romandaki tasvirlerin gerçekçi olması, Bihruz'un iç dünyasının iç konuşma, iç çözümlemeler ve hatta bilinç akımı yöntemleriyle sergilenerek olanca gerçekliği ile verilmesi, yazarın bu tutumuna bağlı olarak, âdeta kendiliğinden gerçekleşir. ${ }^{6}$ Ekrem, kendinden önceki romancılardan farklı olarak, bir tipi önceden bütün boyutlarıyla kafasında tasarlayıp, daha sonra olayların içinde hareket ettirerek, bu tipin olumluluğu ya da olumsuzluğu çerçeveșinde kendi yargılarını okuyucuya aktarma yoluna gitmez. Çevresinde birçok benzerini gördüğü, Tanzimat'ın yarattığı bu prototipi ele alırken, ona yakından, çok yakından bakarak, onı bütün duygu ve düşünceleriyle tanımak ister. Bununla birlikte yazar, bu kadar sıkı takibe aldığı kahramanını kendi serüvenini yaşamakta özgür bırakır; ona hiç bir şekilde müdahele etmez.

${ }^{6}$ Berna Moran, Türk Romanına Eleștirel Bir Bakıs, İletişim Yayınları, C.I, İstanbul 1983, s.59-71. 
Bulunduğu yerden, kendi düşünceleri arasından, belli bir mesafeden bakar ona. Romanı modern yapan, çağının gerçekliğini kavramış yazarın bu tutumudur.

Araba Sevdası'nın romana özgü iç bütünlüğe sahip, ve teknik bakımdan yenilikçi olması, tarihsel içeriğin zorlaması kadar Recaîzade Mahmut Ekrem'in, sezgileri güçlü bir romancı olmasındandır. Ekrem bir tek roman yazmıştır, ama sezgisiyle çağının romanını, çağının ötesine tașıma başarısını göstermiştir. Ne var ki, roman tarihimizde Araba Sevdası, biçimsel bakımdan özgünlüğü yadsınmamakla birlikte, içerik yönünden genellikle zayıf bulunmuştur. İyi işlenmiş olsa da kahramanının anti-kahraman -bu da 19. yüzyıl roman anlayışına uymayan modern bir kavramdır aslındaolması, hikâyesinin basit, sıradan olaylardan oluşması, kuşkusuz böyle düşünülmesinde etken olmuştur. Oysa yalınlığına karşın Araba Sevdast, yazarın ironisi sayesinde vermek istediği mesajla karikatürize edilmiş Bihruz'un şahsında bütün bir çağın kültürel trajedisini yansitır.

Bihruz... alafranga paşazade, kalem efendisi, züppe bir genç. Bir "şık"! Hiçbir romancımızın projektörü bu yalınkat tipi, en basit duygusuna, en küçük fikrine kadar bütün iç dünyasıyla böylesine aydınlatamamıştır." Fakat, "Böyle birini bu kadar çok yönlü ve derinlemesine bir gözleme tâbi tutmada, bunu bir roman kahramanı yaparak bir hiçten ibaret olan hayatını incelikle tasvir etmede ne yarar vardı?” diye düșünülebilir. Esasen romanın can alıcı noktası da budur.

Bihruz Bey, Türk romanının başlangııından çok uzun zamanlar sonrasına kadar kişi kadrosunun seçildiği toplum tabakasından alınma bir tiptir. Bu tabaka ise, "Saray" çevresinden, genellikle devlet ricalinden, konaklar İstanbul'unun kişilerinden oluşur. "Saray"ın öngördüğüu Batılılaşma sürecini de gerçekleştiren bu tabaka olmuştur. Bihruz Bey'in paşa babası azledilmiş bir vezirdir. İstanbul dışındaki memuriyetlerinden dolayı oğlunun tahsiliyle yeterince ilgilenememiș olmakla birlikte, İstanbul'a döndükten ve onu bir "kalem'e" yerleștirdikten sonra “... beyefendi için artık bittabi vâcib görünen Fransızca ile beraber ikinci derecede lüzumu teslim oluman Arabî ve Farisîyi öğrenmek ïzere Bihruz Bey'e başka başka

\footnotetext{
${ }^{7}$ Bkz. İsmail Parlatır, Türk Romanında Tipler: Bihruz Bey, Türk Dili, C. 48 , S. 390-391, Haziran-Temmuz 1984, s. 265-271.
} 
maaşll hocalar tayin etmiş idi." (s. 215). ${ }^{8}$ Bihruz Bey, batılılaşma sürecinin aktif olarak yaşandığı, benimsendiği, irdelendiği bu merkezî ve model sınıfın herhangi bir temsilcisi olarak karşımıza çıkar. Kușkusuz bu sınıfın seçkin niteliklere sahip olanlarından değil; sıradan, ancak taklitçiliğinde aşırıya gitmesinden dolayı sivrilen biri, bir züppe olarak.

Bihruz Bey'in dünyasında kendini Avrupalı gibi hissetmek, çevresine bir Avrupalı gibi görünmek vardır. Böyle görünmenin ilk koşulu da Avrupalılar gibi giyinmektir. Sonra da onlar gibi konuşmak, onların davranışlarını taklit etmek gelir. Avrupalılık ise topluma benimsetilmek istenen yeni yaşama biçimidir. Bihruz kendini bu sanal dünyaya öylesine kaptırır ki, âşık olunca da onlar gibi âşık olmalıdır. Bihruz, işte burada - aşkın da batılı formata uyması gerekir - romanlara başvurur.

Bihruz'un, çağından kaçan, bu yüzden şövalye romanları okuyarak şövalyelik dönemi hayatını yaşamak isteyen Don Kişot'a benzerliğini yapan hususlardan biri budur. ${ }^{9}$ Şu farkla ki, Don Kişot'u hayaller dünyasına iten, geçmiş ama yaşanmış zamanlara çeken, kısaca, çağıyla uyuşamamasıdır. Bihruz'u ise, toplumdan

\footnotetext{
${ }^{8}$ Alıntılar, Recaîzade Mahmut Ekrem'in Bütün Eserleri, (Haz. İ. Parlatır, N. Çetin, H. Sazyek), C.III, Millî Eğitim Basımevi, İstanbul 1997, kitabında yer alan Araba Sevdası'ndan yapılmıştır.

"Don Kişot ile Bihruz Bey arasındaki bu benzerliğe Türk Romanına Eleştirel Bir Bakış adlı kitabında ilk defa Berna Moran işaret etmiştir: "Don Kişot nasıl kendi yarattığı bir hayal dünyasında yaşamışsa Bihruz da kendi icatettiği hir hayal dïnyasında yaşar. Don Kişot, köylü kızı Dulcina'yı nasıl dïnyanın en soylu, en erdemli, en güzel kızı yapmışsa, Bihruz da pişkin, yosma Periveş'in saff bir melek olduğuna inandırır kendini.|...J Diyeceğim, Don Kişot nasıl okudığu romansların etkisinde kalarak ordaki yaşamı taklit etmeye kalkmışsı, Bihruz da okuduğu romanların etkisi altında derin ve sstıraplı bir aşka öykünerek bunun tadını çıkarmaktadır."(s.62). Jale Parla, Don Kişot'tan Bugüne Roman adlı kitabında, “ 'Modernizasyon/batılılaşma külttürel bir yozlaşma olarak gelecekse, hiç gelmese daha iyi olur', fikrini Recaizade Ekrem'in Araba Sevdası adlı romanı pekiştirir. Araba Sevdası'nm başkişisi Bihruz Bey de hir donkişottur." " cümlesiyle Berna Moran'a göndermede bulunur. Jale Parla. (Don Kişot tan Bugüne Roman, İletişim Yayınları, İstanbul 2000. s.74.)
} 
istenen Batılılaşma sürecinin gereği olarak, batılılara özgü davranışları ve batılı aşkı, batılı romanlarda bulabileceğini düșünmesi romanlar dünyasına çeker. Yaşanmamış bir dünyaya... Bunu da Fransız hocası Mösyö Piyer'in aracılığıyla, kendi bilgi ve düșünce dünyası dar olduğundan çoğu yanlış anlamalarla dolu bir okuma ile gerçekleştirdiğini sanır.

Çamlıca Bahçesine şık bir lândoyla gelmiş olduğu için güzel Perîveș'i kibar bir hanım zanneden Bihruz Bey ona âșık olur. Batılı tarzda yapılmış bahçenin, okuduğu romanlardan kalan bazı sahnelerin, Bihruz'un zihninde yarattığı küçük sanal âlem onu yanılsamalara sürükler. Perị̂veş ile refakatçisi Çengi Hanım'ın konuşmalarından kulağına çalınan bir tek "İngiltere" sözcüğü, hiç ilgisi yokken, hanımların kendisinden söz ettiğine inanmasına neden olur:

“...sarışın hanımın zerafetine hayran olup dururken en sonra İngiltere lâfzını işittiği gibi bunu mücerred kendisine firlatılmıș bir ufak taş olmak üzere telâkki etmek istedi. Bunda da esasen hakkı vardl. Çünkü o mecmada kendisinden başka -Ingiltere'dan henüz gelmiş bir mösyö gibi- alafranga giyinmiş kimse yoktu. Böyle bir iltifat-l cihan-klymete nailiyetten dolayı kendisini en birinci bahtiyarlardan addetmeye kalkışan Bihruz...(s. 230)

Bir tek sözcükten böyle asılsız hayallere kapılan Bihruz Bey, okuduğu kitapları ezbere bilen, müthiş bir hayal gücüne, hafızaya ve kültür birikimine sahip Yaratıcı Şövalye Don Kişot'tan elbette çok farklıdır. Okumaları eksik, yetersiz, bilgisiz bir adamdır Bihruz. Esasında nasıl hayal edeceğini, hayallerini nasıl süsleyip sonra onları nasıl uygulayacağını bile bilemez. Bilemez ama, birçok parçası noksan sanal bir dünyada yaşamaktan da kendini kurtaramaz. Bu hayal dünyasını bir bütünlüğe kavuşturmak için Mösyö Piyer'e muhtaçtır.

Bihruz, Çamlıca Bahçesinde, âşık olduğu Periveş'e birkaç kelimeyle hitap etmeyi başardığı gün, onun ve yanındaki arkadaşı Çengi Hanım'ın davranışlarına ne anlam vereceğini bilemeyerek, bir randevu bile alamadan aklı karışmış bir hâlde eve döner. Hocası Mösyö Piyer, ders günü olduğu için onu beklemektedir. Politikayla çok ilgili olan Mösyö Piyer, yemek sırasında, o gün için çok güncel ve önemli bir konuda, Süveyș Kanalı ile ilgili olarak bir gazetede 
okuduğu bir yazı üzerine konuşmak ister. Bihruz'un ciddi konularla ne ilgisi vardır, ne de yeterli anlama gücü. Aklı Perîveş'te ve aşkta olan Bihruz, hocasından o gün yaşadıkları konusunda bir fikir almaktan başka bir şey düşünmediğinden ülkesini çok ilgilendiren Süveyş Kanalı konusunu duymaz bile. Hocasından, aşktan söz etmesini ister. Sinirlendiğini belli etmemeye çalışan Mösyö Piyer, hangi tür aşktan bahsetmesini istediğini sorar. Kendisine dilinin yetersizliğinden dolayı kaba bir biçimde: "de l'amour de femme" ("kadın aşkı") ndan, diye cevap veren ögrencisine iyiden iyiye kızar ve istediğini yapmak yerine onu biraz hırpalar. Hocasının neye kızdığını anlayamayan, onunla birlikte okudukları aşk romanlarından (Paul et Virginie. La Dame aux Camélias, Ihlamurlar Altında, Werther'in Hikâyesi gibi romantik romanlardan) pasajlar hatırlayarak kendi kendine: "Bu akșam Mösyö' ye ne oldu da daima ihtiram ile yâdettiği aşk ve muhabbeti böyle tahkire kalkıştı?" diye söylenen Bihruz Bey'in aklından geçenleri yazar-anlatıcı şöyle aktarır:

"Zavall Bihruz Bey, muallim efendiye hitaben: "Parlon alamur sil vu ple! ${ }^{\cdot 10}$ dediği vakit neler dïşünmüsş idi: gündüzkü sergüzeşt-i âșıkanesini kâffe-i teferruattyla muhtasaran Mösyö Pierre 'e anlattiktan sonra o muhtasaratı muallim efendinin maharet-i lisaniyesiyle giydirilmiş, kuşatılmış, sïslenmiş, kıvraklanmıs olarak tekrar ișitecek idi!.. Evet! Ârâyiș-i gerdîne-i ihtișâm olan duhter-i zerrîn gîsû-yu nâzik-hrram ile ilk nazar-ı âşsıanenin sûret-i teâtisinden bașlanarak bahçeye inişler, lâkın kenarında durış̧lar, gülüssler, söylenişler, yer aynası lâtifesi, pırlanta sohbeti, çiçek muhabbeti, gezinişler, yürüyüişler, randevu talebi, rakîp belâsı, müfarekat-ı keder-bahșa, azînet-i bilâ-veda, iktiham-ı mevâni, takib-i nâ-behengâm, ciüst ï cî̀-yl bî-semere, halecânlar, hiddetler... strastyla ü̧̈er beșer kelime ile söylendikçe Mösyö Pierre bu cümle ve fikraları kendisine mahsus belâgat ve setâretle tevsi ve tezyin ederek tekrar edecek, Bihruz Bey de hunları dinledikçe bu gizzel, bu șairane romanın kahraman bizzat kendisi olduğunu düșünerek mesut ve müftehir olacaktl!" (s. 249)

Yazar-anlatıcının çözümleyerek aktardığı bu duyguların dili, Bihruz Bey'in dili değildir. Yazar, ironik bir biçimde, romantik Tanzimat yazarlarının dilini taklit eder. Cervantes eserinde şövalye

11" "Lütfen aşktan söz edelim." 
romanlarını eleștirme amacı güttüğü gibi Recaîzade M. Ekrem'in eseri de, romantik edebiyata karşı alınmış bir tavırdır. Mösyö Piyer, Bihruz'un romantik duygularının Fransızcasını söyleyecektir. Onun, hayalindeki romanı yaşaması için hem edebî dilde hem Fransızcada iki taraflı desteğe ihtiyacı vardır. Mösyö Piyer, kendisine romanlar okuduğu gibi, yaşadığı/yaşamak istediği romanı da yapmasına yardım edecektir.

Bihruz'un parıltısına kapıldığı dünyanın kapısını olsa olsa romanlar açabilecektir. O kapının anahtarı ise Mösyö Piyer'in elindedir. Oysa Yaratıcı Şövalye Don Kişot, sonu gelmez serüvenleri için gerekli donanıma sahiptir. Eski miğferi kırılınca kartondan da olsa yerine bașkasını koymasını bilir. Uçsuz bucaksız dünyasında açıldığı kırlarda serüvenlerini kendisi yaratır. Yaratıcı Şövalye 'nin bir de gerçekleri söyleyen dostu vardır: Silâhtarı Sanço. Bihruz'un hiç dostu yoktur. Amaçsız, durmadan yalan söyleyerek Bihruz'un yanılsamalarını idare eden yalancı Keşfî, parasını almaktan bașka bir şey düşünmeyen Mösyö Piyer, onu gülünç ama -yazarının da ön sözünde belirttiği gibi- çok hazin ve müellim dünyasina daha çok iterler.

Batılı yașayıșın taklit edildiği bu dönemde, Mustafa Fazıl Paşa'nın yaptırdığı Çamlıca Bahçesinin Araba Sevdası romanında çok önemli bir yeri vardır. Recaîzade'nin romanda uzun uzun tasvir ettiği bahçeye ilk açıldığı yıllarda çok rağbet edilir:

"Süslü hanimları, şık beyleri hâmil birkaç yüz kadar araba hahçenin etrafinı kuşatarak bir zincir-i müteharrik gibi birbiri ardinca muttasil ve müteselsil devrederlerdi" (s.212)

Bihruz Bey'in hikâyesinde Çamlıca Bahçesini alegorik bir mekân olarak düșünmek mümkündür. Burası, devrin ve Bihruz'un alafrangalığını simgelemesi açısından romanın en önemli mekânıdır. Bihruz Bey, cins atları, zarif arabasıyla bahçenin dıșındaki "zincir-i müteharrik" arasına nasıl sıkıșıp kalmıșsa, yașadığı güne ve mekâna da öyle sıkışmıştır. Batılılaşarak kurtulacağı bilincinde olan Türk toplumunun eliti de. Batılı olmanın ne demek olduğunu bilmeksizin bu medeniyet çevresinde tıpkı bir devr-i daim zinciri, bir kısır döngü içindeymişçesine döner durur.

Çamlıca, Bihruz'un gözünde Avrupa'dan bir parçadır: 
“ ...köşe nakillerinin ertesi günü hemen jarden publike şitab ile dahil ve haricini muayene ederek burantn pek alâmod ve hususiyle kendi arzusu vechile arz-l ziynete pek favorabl bir promönad mahalli" olarak görür. " (s.217).

Tanpınar'ın XIX. Astr Türk Edebiyatı Tarihi'nde belirttiği gibi o tarihlerde Çamlıca Bahçesi İstanbul için de aynı anlamı ifade eder:

"Lâkll, kameriyeli, rocaille üslûbu bahçe, Mustafa Fazıl Paşa'nın Çamlıca yolunda köşkünün karşısında yaptırdığı ve halka açtığı bahçe ile hususî hayattan şehir hayatına doğru taşar. Alafiranga muaşeret, o zamanlar Şehzadebaşı, Beyazıt ve Aksaray semtlerinde toplanan vezir konaklartyla İstanbul'un içine asıl Türk halkin arasina sokulur. Bu araba sevdalarmin, Sahra-yı cedid köșklerinin, Çamlıca bağlarının ve Boğaz yalılarının, büyük koruların zengin, teșrifatl, tenperver ve müsrif mevsimidir. Hülâsa, müreffeh sinuflarda, ferdî hayat hemen her safhasinda mâhiyeti tam bilinmeyen garba doğru kaymıştır." 12

Yine Tanpınar'ın bu devrin toplumunun yaşama biçimi hakkında söyledikleri, Araba Sevdası'nı ve Bihruz'u yaratan iklimi, arka plânı bize gösterir:

"Abdülaziz zamanı, zevkte, eğlencede, elbise ve muaşerette mirasına konduğu ilk Tanzimat ylllarının attı̆̆ tohumların geliştiğini görür. Hudutları hâlâ üç kıtada çalkanan İmparatorluğun bütün imkânları, saray ve etrafinda toplanmıștır. Aslında yaratıcl olmamaktan doğan rahatsızlı̆̆ını bin türlü israf ve debdebe ile ¿tututmaya çalışan bir mirasyedi yaşayışı bu zamanın ayırıcı vasfidır. Beyoğlu, avrupall lokanta ve kahveleriyle, en basit gündelik ihtiyaçtan, en pahall zevk unsuruna kadar her seyi Avrupa'dan tedarik eden zengin mağazalartyla, gece hayattyla, eğlence yerleriyle Avrupa hayatımın küçük bir nümunesini verir. Her modastyla büyük

" jarden publik(jardin public): Umumî bahçe.

alâmod(à la mode): Modaya uygun.

favorabl (favorable): Uygun, müsait.

promönad (promenade): Gezinti.

2 Ahmet Hamdi Tanpınar, XIX. Asır Türk Edebiyatı Tarihi, Ibrahim Horoz Basımevi. 2.b., İstanbul 1956, s. 127. 
Avrupa merkezlerine, bilhassa Paris'e tâbidir. Giyim ve kuşamda, debdebe ve sefahatta onu takip eder, eğlencede onun artiklartyla geçinir. Bender fabrikasından araba, Bulvar tiyatrosu, kafeşantan, Fransiz veya İngiliz tarzl mobilya, cins yarıs ve araba atı, alafranga sofra, Fransiz şarabl, ecnebî mürebbiye, yabancı dil hocasl, bazı zümreler için olsa dahi şehir hayatının -orta oyunu ve karagöz gibi yerli gelenekler ve biraz sonra doğacak yeni edebiyatla beraber derece farklartyla besleyecek- unsurları hâline gelir. "13

Bihruz da, yetersiz okumalarından, Beyoğlu mağazalarında satılan mallardan ve orada gördüğü yabancılardan aldığı ilhamla, "mahiyetini [hiç] bilmediği garb[tan]" bir örnek olan bu bahçeden, hayalinde yarattığı bir garip alafrangalık, Avrupalılık dünyasına dalar. İstanbul'un kaymak tabakasından bu paşazade, cahil, kapasitesiz ve saftır. Batı medeniyetinin yüzeyde görünen yanları peşinde koşan içinde bulunduğu sınıf gibi Bihruz da sadece görüntülerin peşinde koşar. İflâs etmek üzere olan devleti gibi, Bihruz da iflas etmek üzeredir. Tanzimatçılar eskiyi reddetmekle işe başlamışlardı. Bihruz ise eskiyi hiç tanımaz, geçmişiyle bağları kopmuştur, hattâ yoktur. Hocası Fransız Mösyö Piyer'in parasını ödeyebildiği müddetçe onun ebedî öğrencisi olacaktır. Kendi başına okuyamaz, anlayamaz. Yönetilen, yönlendirilen, kendi idraki olmayan, bireysel düşünmeyi yaratamamış toplumun bir kişisidir. Tanpınar'ın 'köksüz gölgeler kitabı" ${ }^{\prime 14}$ olarak değerlendirdiği Araba Sevdası'nın Bihruz'u bu durumda bir "gölge" kişi olmaktan başka ne olabilirdi?! Recaîzade'nin, kahramanının kendisine yarattığı bu alafranga dünyanın dilini ve kafasının işleyiş biçimini okuruna büyük bir ustalıkla gösterebilmesi, onun ne kadar "gerçek bir gölge" olduğunun kanıtıdır. Romancının, Batılılaşma sorunsalı içindeki toplumdan seçtiği bu kişi, o toplumun esasında en temayüz etmişlerindendir:

"Binenaleyh Bihruz Bey'in ekipajı-yukarıda tarif olunduğu vechile- bahçenin etrafint muttasıl ve müselsel devreden zencir- $i$ müteharrikin birinci halka-i mübahatı addolunmaya lâyık idi. "(s. 20)

\footnotetext{
${ }^{13}$ A.g.e., s. 127.

${ }^{14}$ A.g.e., s. 486.
} 
Yazarın burada, Bihruz'un giyim kuşamı ve arabasının seçkinliğini kastederek yaptığı açık ironisinin arkasında "Saray"dan bașlayarak bu sınıfın tutkulu Batı hayranlığına da gönderme olduğunu düşünm̦emek için hiçbir neden yoktur.

René Girard, Romantik Yalan ve Romansal Hakikat (Mensonge romantique et Vérité romanesque) adlı eserinde edebiyatta, özellikle modern romanda ben ve öteki kavramları dolayısıyla taklitçilik üzerinde durur. Hatta modern romanın temel yapısını oluşturan olgunun "ötekinin arzusumu taklit etmek" olduğunu iddia ederek bu düşüncesini sistemleştirir. Don Kişot, serüvenini, bütün şövalyelerin en büyüŭgü olarak gördüğü Amadis'i taklit ederek aramaya dayandırır. Emma Bovary, genç kızlığında okuduğu romantik romanların kadın kahramanlarını taklit eder. Girard'ın metafizik arzu diye nitelendirdiği bu tür arzu duyma, ötekinin arzusunu taklit ederek, özne için, o arzunun nesnesinin önem kazanması demektir. Don Kişot'un kendisine yarattığı hayal dünyasında, berberin tıraş tasını Mambrino'nun miğferi olarak görmmesi, çevresinde tıraş tasına, tıraş tası diyenleri öldürmekle tehdit etmesi, taklit ettiği Amadis'in peşine düştïğü nesnelerin, Amadis'in .. /ısuna bağlı olarak değer kazanmasıdır.

"Saray"dan ve padişahtan başlayarak Bihruz'un içinde bulundığu toplum tabakası bir başka medeniyetin, ötekinin hayranıdır. Ona göre arzu eder ve onun nesnelerine sahip olmak ister. Bú da taklidi doğurur. Devleti düştüğg̈ güçsüz durumdan kurtarma projesi demek olan Batılılaşma, seküler Batı'nın yarattı̆̆ı yeryüzü mutluluğunun nesnelerini de işaret etmektedir. Dönemin aydınları, Batı'yı taklit etmede birtakım ilkeler ve sınırlar koymaya çalışırlar. Bütün edebiyat bu konu üzerinde yoğunlaşır. Bunu yaparken de, öncelikle onun, en kestirme ve etkili yol olarak görülen edebiyatı taklit ederek işe başlanır. Batı'yı taklit etme bireylerin seçimi olarak değil, "Iktidar"ın arzusu olarak yapılacaktır. Kısacası, "Iktidar"ın ötekinin arzusuna duyduğu arzu, toplumun arzusu olmak zorundadır. Toplumun refah içindeki tabakası için bu arzuyu duymak hiç de zor değildir. Batı malları doğrudan doğruya arzuyu kamçılayacak niteliktedir. Bu kolektif taklitçilik ortamının bir züppeler güruhu yaratması kaçınılmazdır. ${ }^{15}$ Bu dönemde bir salgın gibi toplumu saran züippeliği yaratan psikolojik ortama Koestler' in șu tanımı tıpatıp uyar:

15 Bkz. Köksal Alver, "Züppeliğin Sosyolojisi: Türk Romanında Züppe Tipler", Hece, (Türk Romanı Özel Saylsi), S.65-66-67, Mayıs-HaziranTemmuz, 2002, s. 252-267. 
"Züppelik, kaynaklarl ve yapıları birbirinden bütünüyle ayrl olan ama insanın kafasında ayrilmayacak ölçüde birbirine girmiş olan iki ayrı değerler sisteminin ruhbilimsel olarak karıșmasının sonucunda ortaya çıkar." 16

Bu nedenle, alafranga züppe tipinin, bizde roman yazılmaya başlanır başlanmaz, kişi kadrosunun başında yer alması bir rastlantı değildir. Batılılaşma bir sorunsal olmaktan çıkamadığı için, bu tip bazı değişimler geçirse de Türk romanında varlığını sürdürmeye devam etmiştir.

Bihruz Bey, Babıâli'de kalemde öğrendiği, Fransız hocası ile geliştirmeye çalıştığı Fransızcasıyla, Terzi Mir'den pardesüsü, Herald işi potinleri, Albert Gün'den alınmış gömlek, kravat, çorap ve mendilleri, berber İzidor'dan tıraşı ve Bender fabrikasından arabası, ekipajı, kendisiyle Fransızca konuşabilecek üniformalı Rum arabacısı Andon ve Ermeni ușağı Mișel ile toplumundaki züppelerin en önde gelenlerindendir. Fakat Bihruz'un ayırıcı bir özelliği vardır: Batılı olmak, alafranga yaşamak gerektiğine duyduğu katıksız inanç!

Girard, kitabında, Proust'un romanı dolayısıyla züppelik konusunun uzun uzun çözümlemesini yapar. ${ }^{17}$ Proust'un züppesinin Saint-Germain semtini, herkesin girmeyi düsslediği efsanevî krallık sandığını; züppe için Saint-Germain'in büyülü miğfer, züppe olmayan için tıraş tası olduğunu söyler. Çamlıca Bahçesinin anlamı da Bihruz için bir parça öyledir. Bihruz orada, Batı'da bir yerdeymiş gibi hareket eder. Anlayıp anlamayacaklarını düșünmeden herkesle Fransızca konuşur. Çoğu Fransızca sözcüklerden, cümlelerden oluşan konuşmasını Periveş'in anlayacağından öylesine emindir ki... Çamlıca bahçesinin "efsanevî Batı" olmadığını ona hatırlatması gereken yerli halk karşısında iki ayrı dünyayı ters yüz eden şu ilginç yakıştırmayı yapar:

“...mavi dizlikli, kırmızı kuşakll, dar pantalonlu, şam hırkall, gecelik entarili, saltast omuzunda, setresi kolunda yüzlerce seyircilerden her adında bir tanesiyle rûberû geldikçe bu hâlden sikllip 'Kes kö se kö sa? Es kö lö karnaval e deja arive? diyerek geri dönmeye mecbur oldu' ${ }^{\text {,18 }}$ (s. 298)

\footnotetext{
${ }^{16}$ Köksal Alver, A.g.y. , s. 253.

${ }^{17}$ René Girard, Romantik Yalan ve Romansal Hakikat, Çev. Arzu Etensel İldem, Metis Yayınları, İstanbul 2001, s.182.

${ }^{18}$ Bu da nedir? Karnaval vakti oldu mu ki!
} 
Bihruz'un buradaki yanılsaması, yel değirmenlerini dev, koyun sürülerini savaşmak üzere olan ordular zanneden Don Kişot'un yanılsamaları kadar ironiktir. Bihruz da batılı bir mekân olarak gördüğü Çamlıca Bahçesine, memleketin yerli halkını yakıştıramadığı için kılık değiştirmiş karnaval insanları gördüğünü düşünmek ister.

\section{Sonuç}

Tanrısal değerlerin ve yüce sultanın yol göstericiliğinin sona ermesi ve Batı'nın değerlerinin bunların yerine ikame olunmasıyla Bihruz ve Bihruz gibilerin yanılsamaları bașlar. Bihruz bu dönemin karikatürü, bir gerçekliğin abartılmıș çizgisidir sadece. Don Kişot'un yaşadığı günle uyumsuzluğu yanılsamasını yaratır. Toplumu kurtarma adına geçmişe döner, idealisttir. Tanrısal değerlerin peşindedir. Oysa gününün toplumunda bunlar yok olmak üzeredir. Bihruz ise, tam tersine geçmişin değil, belirsiz bir geleceğin peşinde koşarken, içinde bulunduğu zamanla, daha doğrusu, kendi sınıfının dışında kalan toplumun büyük çoğunluğuyla uyumsuzluğunu yaşar. Bihruz, içinde bulunduğu batılılaşmacı katmanın hayatını yaşama peşindedir. Geçmişe değil de geleceğe dönük olmasıyla bir bakıma gerçekçidir. Her iki roman kahramanı, Don Kişot da, Bihruz da temsil ettikleri toplumla birlikte bir sorunsal karşısındadırlar. Yalnız, Bihruz, Batı toplumu gibi bireyleşmiş, burjuvaziyi yaratmış, aklın ve insanî değerlerin üstünlüğüne inanarak modern çağı yaratmış bir toplumun üyesi değildir. Toplumun hayatında ekonomi ve bilgi alanında herhangi bir değişim, bir dinamizm yokken bir gün gelmiş, "Saray" ve "Sultan" -iktidar mevkiinde- iktidarsızığını örtülü olarak söyleyerek toplumundan değerler sistemini değiştirmesini istemiştir. Toplum yüzyıllardır inandırıldığı değerleri, yine iktidar öyle istediği için değiştirmek zorundadır. İşin kötüsü yeni değerlerin neler olması gerektiği de bilinmez. Ayrıca manevî değerlerle dünyevî değerlerin karşı karşıya gelmesi söz konusudur. Dönemin seçkinlerinden olan yazarlar, neyi değiștirmek, eskinin yerine neyi koymak gerektiğini bulmak için çırpınırlar. Taklide dayanan dünya bașıboș, hamisiz kalan insanları bir bataklık gibi çekmektedir. Kendi aklına güvenme durumuna gelmemiş, kolektif düşünmekten kurtulamamış ve bireysel sorumluluğunu taşımaya hazır olmayan bu toplumun kişisi, Batı'yı taklit ettiği için, birey olamadan, bireyin kaçınılmaz kaderi olan yalnızlığa mahkûm olur. Birey olamadan yalnız olmak, dalından kopmuş bir yaprak gibi sürüklenmek demektir. Bihruz yapayalnızdır. Ailesinin 
dünyasına yabancıdır. Âşık olduğunu sandığı kadınla arasında hiçbir iletişim kurmaya muktedir olamaz. Yazdığı mektup, konuşması saçmalıklarla doludur. Hayranı olduğu Batı'yı öğrenmek için yanında tuttuğu hocası Mösyö Piyer'in ciddi hiçbir konuşmasını anlayamaz. Mösyö Piyer de parası için katlandığı bu öğrencinin suyuna gider. Kendisi gibi bir züppe olan arkadaşı yalancı Keşfî onu sürekli aldatır. Çevresinde herkes onu aldatmanın peşindedir. O kadar yalnızdır ki, sürekli kendi kendisiyle konuşur ve yanılsamalar içinde yaşar.

Recaizade M. Ekrem, bu dönemi yaşamıştır. Bihruz'un yaşadıklarına ve hissettiklerine hiç de yabancı değildir. Bir bakıma Bihruz'dur o. Kahramanına şefkati, onu o kadar iyi anlamasından ileri gelir. Girard, romancı için "dönüşüme uğramış bir kahramandır" 19 der. Şu söyledikleri Ekrem için de geçerlidir:

"Proust'un anlatıclsı, tüm romanclar gibi, ömrünün "duvarsız müzesinde" özgürce bir salondan diğerine geçer. Romancl-anlatıcl, tüm yamilgilarından arınmış, arzularını yenmiş ve romansal zarafetle zenginleşmiş Marcel'den başkası değildir. Deha sahibi Cervantes de arzularından kurtulmus bir Don Kişot'tur; tıraş kabinı artık tıraş kabl olarak alglayan ama yine de eskiden onda Mambrino'nun miğferini gördüğünü unutmayan bir Don Kişot. Bu yanılsamalardan arınmış Don Kişot yapttta ancak bir an görülür, sonuç bölümünde ölmekte olan Don Kişot'tur bu.[...] Eğer aynı nesne kendisi için önce bir büyülü miğfer sonra basit bir ttraş kabl olmasaydl Cervantes de Don Kişot'u yazamazdl. Romancı arzuyu yenmiş bir adamdır ve o arzuyu anımsadı̆̆ için bir karşılaştırma yapabilir." 20

Ekrem de, mahiyetini kavramak için çırpındığı Batı dünyası karşısında yanılsamalar yaşamanın ne olduğunu bildiği için Bihruz'u yaratabilmiştir. Don Kişot gibi Bihruz da, romanın sonunda büyük yanılsamasını farkeder: Perîveş'in ölmemiş olduğunu, sandığı gibi soylu bir hanım değil, ancak bir kira arabasına binebilecek durumda bir yosma olduğunu anlar. Yanılsamasından çıkmak, onu Don Kişot gibi iyileştirmez, bir hiçlikten bir başkasına fırlatır. Romanın sonunda Perîveş'in kırmızı şemsiyesine hitaben "Pardon!" [diyerek] geldiği tarafa dön[er], koşa koşa gitmeye baş[lar]. Romanın bu son sözleri çok anlamlıdır. Bihruz'un geldiği yöne doğru koşması, bulunduğu kısır döngüden çıkamayacağının bir ifadesidir.

${ }^{19}$ Girard, s. 189.

${ }^{20}$ A.g.e.,s. 189. 
Yanılsamalar içinde olan, şövalyelik çağında yașayan Don Kişot ölür. Modern Çağ’a deliliğinden kurtulmuş öbür yanı kalır. Modernitenin birtakım hastalıklarını sürdürecek olsa da, ayakları üzerinde duracak ve daima ileriye doğru koşacak bireyi yaratarak! Oysa bir hiçliğin içinde kalmış Bihruz'dan başka Bihruz'lar doğarak çoğalacaklardır. Recaîzade Mahımut Ekrem'in romanını büyük yapan bir hiçten ancak hiç çıkacağını göstermiş olmasıdır. ${ }^{21}$ Kendini idare edemeyen kişilerden oluşmuş, vesayet altındaki toplumda hep aynı kalan sorunsala değişik bir bakış açısından bakmaya çalıșan iktidarlar ve onların yazarları yeni kukla kișiler yaratacaklardır. Bihruz ise bizatihi kendisi olduğu için yaşıyor. Yazarı onu kendi istediği için öyle yaratmadı, öyle olduğu için romanına girdi ve öyle olduğu için yaşıyor. Araba Sevdası bugüne kadar așılamayan Batılılașma sorunsalı karşısında yanılsamalar hâlâ sona ermediği için, hep yepyeni ve tek roman klâsiğimiz olma özelliğini koruyor.

\footnotetext{
${ }^{21}$ Jale Parla, Babalar ve Oğullar kitabında, Araba Sevdası'nın konusunun "hiçlik" olduğınu söyler. Tanzimat'ı "karşıt epistemolojilerin bulușma noktası" olarak tanımlayan yazar, Recaizade M. Ekrem ve eseri hakkındaki yargılarını şöyle belirtir: "Yazarı, çağının kültürel karmaşasının tam bilincindedir: karșıt epistemolojilerin bulușma noktasındaki boșluğu görïr ve hu boșlukta hiçbir gerçekliğin tanumlanamayacağından ïrker. Yanılsama ile gerçeklik arasındaki mesafenin aşılması için gerekli yazın yöntemi ya da yöntemlerinin Tanzimat döneminde yapılmıs ilk roman denemelerinden çıkamayacağı inancındadır; bu karamsarlığını Araba Sevdası'nı baştan sona bir yazma ve okuma parodisi biçiminde kurguluyarak dile getirir. Recaîzade Ekrem'i çağdașları arasında benzersiz kılan, tüm eylemleri eylemsizliğe, tüm öykü̈mmeleri başarısızlığa, duygıryu abes duygusallığa ve düssü (ki yaratıcılığı içerir) yokluğa dönüştüren bir roman yazmış olmasıdır. " (İletișim Yayınları, İstanbul 1990, s. 105.)
} 